\title{
Antioxidant potential and iodine accumulation in tomato (Solanum lycopersicum L.) seedlings as the effect of the application of three different iodobenzoates
}

\author{
Mariya Halka*, Sylwester Smoleń, Iwona Ledwożyw-Smoleń
}

Department of Plant Biology and Biotechnology, Faculty of Biotechnology and Horticulture, University of Agriculture in Krakow, Al. 29 Listopada 54, 31-425 Krakow, Poland

\begin{abstract}
Iodine (I) has a beneficial effect on plant growth, development and antioxidant activity. The study aimed to compare iodine uptake after the application of iodobenzoates (2-iodobenzoic acid (2-IBeA), 4-iodobenzoic acid (4-IBeA) and 2,3,5-triiodobenzoic acid (2,3,5-trilBeA)) as well as potassium iodide (KI) to tomato seedlings. One of the main tasks was to evaluate how the tested compounds applied in different concentrations $(5,10,25$ and $50 \mu \mathrm{M})$ affect the growth and antioxidative potential of tomato seedlings. Negative effect on growth and development of tomato seedlings was noted for 4-IBeA applied in 10-50 $\mu \mathrm{M}$ I concentrations. The 2,3,5-triIBeA application affected shoot deformation. All tested iodine compounds increased iodine level in leaves and roots of tomato seedlings. Iodine after KI application was accumulated mainly in leaves, while after iodobenzoates treatment in roots of tomato seedlings, which is probably related to their weaker transport to the upper parts of the plant. Tested compounds variously modified the content of ascorbic and dehydroascorbic acids in tomato leaves depending on applied concentration. KI treatment improved ascorbate peroxidase activity, but all iodobenzoates decreased APX and catalase activity in leaves. 4-IBeA (5 $\mu \mathrm{M} \mathrm{I})$ and 2,3,5-triIBeA (25 and $50 \mu \mathrm{M} \mathrm{I}$ ) increased guaiacol peroxidase activity in leaves. It can be concluded that mechanisms responsible for plant oxidative metabolism were variously affected by the iodine compounds and its concentration in the nutrient solution.
\end{abstract}

Keywords: antioxidant activity, catalase, iodine biofortification, organoiodine compounds, peroxidase

Abbreviations:

2-IBeA, 2-iodobenzoic acid; 4-IBeA, 4-iodobenzoic acid; 2,3,5-triIBeA, 2,3,5-triiodobenzoic acid; AA, ascorbic acid; APX, ascorbate peroxidase; BeA, benzoic acid; CAT, catalase; DHA, dehydroascorbic acid; KI, potassium iodide; POX, guaiacol peroxidase; ROS, reactive oxygen species.

\section{INTRODUCTION}

Iodine (I) is an essential micronutrient in a human diet. It is involved in several processes in human and animal organisms including the synthesis of thyroid hormones - triiodothyronine and thyroxin. It also plays an important role in the prenatal period and during pregnancy (Wang et al., 2019). Iodine deficiency may be associated with a number of metabolic, growth and developmental disorders. The commonly used method for introducing iodine into the human diet is iodisation of table salt (World Health Organization, 2007). Unfortunately, the losses of iodine from table salt during storage transport and cooking can reach up to $90 \%$ (Winger et al., 2008). Iodine biofortification of vegetables can be an alternative method in the fight 
against iodine deficiency in the diet (Gonella et al., 2019).

Most of the works on iodine biofortification of plants have focused on using inorganic forms of iodine such as potassium iodide $(\mathrm{KI})$ and potassium iodate $\left(\mathrm{KIO}_{3}\right)$ (Medrano-Macías et al., 2016a). Only a few publications have tested the application of organic iodine compounds such as iodoacetic acid to water spinach (Weng et al., 2008) or iodosalicylates to tomato seedlings (Halka et al., 2019a - our previous study).

It is believed that iodine is not essential for plant nutrition. However, it can be classified as a beneficial element for plant growth and development for it is involved in many processes in plants such as environmental adaptation, stress tolerance and antioxidant capacity (Medrano-Macías et al., 2016a; Gonzali et al., 2017). The application of inorganic iodine forms $\left(\mathrm{I}^{-}\right.$or $\left.\mathrm{IO}_{3}^{-}\right)$to plants can influence the different metabolic processes, antioxidant activity, the content of biologically important compounds such as sugars, phenolic compounds as well as on yield of plants (Medrano-Macías et al., 2016a). There are also a few studies indicating the effect of mineral iodine on plant oxidative metabolism (Blasco et al., 2008; Blasco et al., 2011a). A study by Blasco et al. (2011a) showed a lower concentration of $\mathrm{H}_{2} \mathrm{O}_{2}$ (molecules whose content often increases as a response to a wide range of biotic and abiotic stress) after the $\mathrm{I}^{-}$lettuce treatment. In contrast, the $\mathrm{IO}_{3}^{-}$form caused an increase of this reactive oxygen species (ROS) compared to the control lettuce plants (Blasco et al., 2011a). Research conducted by Blasco et al. (2008) shows that inorganic forms of iodine such as $\mathrm{I}^{-}$and $\mathrm{IO}_{3}^{-}$can improve total phenolic level, ascorbic acid (AA) and dehydroascorbic acid (DHA) content in lettuce, with a stronger effect exerted by $\mathrm{I}^{-}$(Blasco et al., 2008; 2011a). Some studies have also shown an impact of exogenous iodine on antioxidant enzyme activities (Blasco et al., 2011a; Medrano-Macías et al., 2016b). For example, iodine applied as $\mathrm{I}^{-}$to lettuce caused a decrease, while $\mathrm{IO}_{3}^{-}$improved the activity of superoxide dismutase (SOD). Both forms of iodine, and $\mathrm{IO}_{3}^{-}$in particular, tend to increase the catalase (CAT) and ascorbate peroxidase (APX) activity in lettuce (Blasco et al., 2011a). The study conducted by Medrano-Macías et al. (2016b) on iodine biofortification of tomato seedlings showed no effect of iodine application on CAT and APX activity. Our previous study with iodine biofortification of young tomato plants using organic forms - 5-iodosalicylic acid (5-ISA) and 3,5-diiodosalicylic acid (3,5-diISA) showed higher APX activity for 5-ISA at a dose of $50 \mu \mathrm{M} \mathrm{I}$, but decreased CAT activity at doses of 5, 10, 25 and $50 \mu \mathrm{M}$ I. The application of higher doses of 3,5-diISA significantly decreased APX, POX and CAT activities in tomato seedlings (Halka et al., 2019a).

The issue of iodine effect on the antioxidant potential of plants is very important due to the plant defences against ROS and oxidative stress in general. Under the influence of oxidative stress many processes and changes in plants can occur, the monitoring of which is important in terms of food safety and benefits for the consumers.

In our study, we focused on iodine biofortification of tomato seedlings using iodobenzoates as a source of iodine. The research was conducted on seedlings because of the limited information available on the influence of iodobenzoates on plants and recommended doses that should be applied. Iodobenzoates are derivatives of iodine and benzoic acid $(\mathrm{BeA})$, the latter being a direct precursor of salicylic acid (SA). SA is a plant hormone involved in the activation of defence response and playing an important role in response to abiotic stress (Vlot et al., 2009). In plants, BeA is an important structural element for numerous metabolites such as hormones, cofactors or defence compounds. Many natural products that are BeA derivatives or contain benzoyl/benzyl moieties have also medicinal or nutritional values for humans (Widhalm and Dudareva, 2015). BeA is naturally synthesised by plants and belongs to the group of carboxylic acids. These organic compounds are secreted to the rhizosphere to facilitate the absorption of minerals and are also associated with soil elevation weathering and mineralisation (van Hees et al., 2000). Usually, there is a low concentration of organic acids from this group of carboxylic acids (less than $50 \mu \mathrm{M}$ ) in soil, especially BeA. However, some plants can accumulate $\mathrm{BeA}$ in the soil as an allelochemical that interferes with the growth of plant competitors (Kaur et al., 2005). In addition, BeA plays a signalling role under the stress conditions. Exogenous application of BeA to the soil induces the tolerance to heat, drought and chilling stress in tomato plants (Senaratna et al., 2003). The exogenous application of $\mathrm{BeA}$ and its derivatives to the nutrient solution revealed that these compounds can be taken up by tomato roots and transported to the upper parts - leaves and fruits. The application of BeA in $25 \mu \mathrm{M}$ caused a 1.9 -fold increase in the content of this compound in roots and a 5 times increase in tomato fruits compared to control plants (Halka et al., 2019b). The influence of iodobenzoates on seedlings of tomato plants has not been examined before.

Our experiment aimed to describe the uptake of iodine by tomato seedlings using iodobenzoates: 2-iodobenzoic acid (2-IBeA), 4-iodobenzoic acid (4-IBeA) and 2,3,5-triiodobenzoic acid (2,3,5-triIBeA). Treatment with an inorganic form of iodine, i.e., KI was applied as a reference combination. An important task was also to compare the impact of these compounds on the physiological state of plants evaluated by the antioxidant potential and sugar metabolism of tomato seedlings.

\section{MATERIALS AND METHODS}

\section{Plant materials and treatments}

The experiment was conducted in the growth chamber at the University of Agriculture in Krakow. The seeds of tomato plants (Solanum lycopersicum L.) 'Kmicic' were germinated in pots filled with peat substrate. 
For one week, seeds were watered only with tap water. At the two-leaf stage, plants were transplanted to $10-\mathrm{mm}$ diameter pots (volume $0.5 \mathrm{dm}^{3}$ ) filled with perlite. The tomato seedlings were watered with $1 / 2$ Hoagland solution for one week (nutrient solution No. 2 - Hoagland and Arnon, 1950). Full Hoagland basic stock solution No. 2 containing (ppm) N 210; K 235; Ca 200; P 31; S 64; Mg 48; B 0.5; Fe 1; Mn 0.5; Zn 0.05; $\mathrm{Cu}$ 0.02; Mo 0.01 was used. After one week, different iodine compounds and BeA were first introduced to the plants. The solutions of tested compounds were applied every other day alternated with a $1 / 2$ Hoagland solution (we diluted the basic stock solution twice). The studied treatments were: (1) control (treatment only with $1 / 2$ Hoagland solution); (2) control + ethanol $\left(0.5 \mathrm{~cm}^{3}\right.$ of ethanol $\cdot \mathrm{L}^{-1}$ of $1 / 2$ Hoagland solution); (3) BeA (Chempur, Poland) concentrations $5 \mu \mathrm{M}, 10 \mu \mathrm{M}, 25$ $\mu \mathrm{M}, 50 \mu \mathrm{M}$ dissolved in $1 / 2$ Hoagland solution; (4) KI (Sigma-Ardrich - MERCK, Poland) concentrations $5 \mu \mathrm{M}, 10 \mu \mathrm{M}, 25 \mu \mathrm{M}, 50 \mu \mathrm{M}$ dissolved in 1/2 Hoagland solution; (5) 2-IBeA (Sigma-Ardrich-MERCK, Poland) concentrations $5 \mu \mathrm{M}, 10 \mu \mathrm{M}, 25 \mu \mathrm{M}, 50 \mu \mathrm{M}$ dissolved in 1/2 Hoagland solution; (6) 4-IBeA (Sigma-Ardrich - MERCK, Poland) concentrations $5 \mu \mathrm{M}, 10 \mu \mathrm{M}, 25$ $\mu \mathrm{M}, 50 \mu \mathrm{M}$ dissolved in $1 / 2$ Hoagland solution; (7) 2,3,5-triIBeA (Sigma-Ardrich - MERCK, Poland) concentrations $5 \mu \mathrm{M}, 10 \mu \mathrm{M}, 25 \mu \mathrm{M}, 50 \mu \mathrm{M}$ dissolved in $1 / 2$ Hoagland solution. Ethanol in volume $0.5 \mathrm{~cm}^{3} \cdot \mathrm{L}^{-1}$ of $1 / 2$ Hoagland solution was added for $\mathrm{KI}, \mathrm{BeA}$ as well as for all iodobenzoate treatments due to the poor solubility of these compounds in water. BeA treatments were used as reference combinations to iodobenzoates. The total number of applications was five with the last one occurring on the 12th day of tomato seedlings cultivation in perlite. The plant sampling was conducted on the next day after the last application.

Each study treatment consisted of four replicates with four plants per replicate (16 plants per each treatment for each concentration). The total number of plants in the experiment was 352. During cultivation, plants were lightened with a $600-\mathrm{W}$ high-pressure sodium lamp maintaining 10-h light/14-h dark photoperiod. Lamps were suspended $100 \mathrm{~cm}$ from the plants. The air temperature was $25^{\circ} \mathrm{C}$ during the day and $20^{\circ} \mathrm{C}$ at night. The experiment was repeated twice.

\section{Plant analysis}

The fresh weight of leaves, stems and roots of tomato seedlings was measured during the plant sampling. Plants samples were collected, washed in tap water and rinsed in distilled water. Chemical analyses of plant material were performed in dry and fresh samples.

\section{Iodine content}

To determine the iodine content in tomato leaves, stems and roots, plant material was dried at $50^{\circ} \mathrm{C}$ in a laboratory dryer with forced air circulation and ground in variable speed rotor mill Pulverisette 14, FRITSCH using $0.5 \mathrm{~mm}$ sieve. Double-distilled water of $10 \mathrm{~cm}^{3}$ was added to $0.5 \mathrm{~g}$ of milled leaves, stems or roots and mixed. Then $1 \mathrm{~cm}^{3}$ of $25 \%$ TMAH was added to the samples and mixed again. Prepared samples were incubated for $3 \mathrm{~h}$ at $70^{\circ} \mathrm{C}$. After incubation, samples were cooled and filled with double-distilled water up to $30 \mathrm{~cm}^{3}$. Plant samples were centrifuged for $15 \mathrm{~min}$ at $4,500 \mathrm{rpm}, 5^{\circ} \mathrm{C}$ directly before the analysis. Iodine content was analysed with the use of ICP-OES spectrometer (Prodigy, Teledyne Leeman Labs, USA; PN-EN15111, 2008; Smoleń et al., 2016).

\section{Ascorbic and dehydroascorbic acid content}

The content of initial AA and total AA was determined only in tomato leaves. The sample of $2 \mathrm{~g}$ of fresh leaves was homogenised with $8 \mathrm{~cm}^{3}$ of $2 \%$ oxalic acid and centrifuged for $15 \mathrm{~min}$ at $4,500 \mathrm{rpm}, 5^{\circ} \mathrm{C}$. Supernatants were collected, further centrifuged for $10 \mathrm{~min}$ at 10,000 rpm and analysed using Beckman PA 800 Plus capillary electrophoresis (CE) system with DAD detection. Capillaries of i.d. $50 \mu \mathrm{m}$, o.d. $365 \mu \mathrm{m}$ and the total length of $50 \mathrm{~cm}(40 \mathrm{~cm}$ to the detector) were used. The negative power supply of $-25 \mathrm{kV}$ was applied (Smoleń et al., 2016). The running buffer solution containing $30 \mathrm{mM} \mathrm{NaH}_{2} \mathrm{PO}_{4}, 15 \mathrm{mM} \mathrm{Na}_{2} \mathrm{~B}_{4} \mathrm{O}_{7}$ and $0.2 \mathrm{mM} \mathrm{CTAB}$ ( $\mathrm{pH} 8.80$ ) was prepared as proposed by Zhao et al. (2011).

For total AA content determination, $50 \mathrm{mM}$ DTT (dithiothreitol) was added to the obtained supernatant. The level of DHA was calculated by subtracting the initial AA level from the total AA level obtained after DHA reduction. Determination of initial AA and total AA was performed in two independent measurements using the CE technique (Dresler and Maksymiec, 2013).

\section{Enzyme activity assay}

The samples of $1 \mathrm{~g}$ of fresh leaves were homogenised with $100 \mathrm{mM}$ phosphate buffer ( $\mathrm{pH}$ 7.5) containing $1 \mathrm{mM}$ EDTA and 1\% PVP-40 (CAT and guaiacol peroxidase $(\mathrm{POX}))$ or $1 \mathrm{mM}$ EDTA, 1\% PVP-40 and $1 \mathrm{mM}$ AA (APX). Homogenates were centrifuged for $15 \mathrm{~min}$ at $4,500 \mathrm{rpm}, 5^{\circ} \mathrm{C}$. Supernatants were collected and further centrifuged for $10 \mathrm{~min}$ at $10,000 \mathrm{rpm}$. The supernatants were used for further analysis.

APX activity was measured according to Nakano and Asada (1981). The assay mixture $\left(2 \mathrm{~cm}^{3}\right)$ consisted of $50 \mathrm{mM}$ phosphate buffer, $1 \mathrm{mM}$ EDTA, $5 \mathrm{mM}$ ascorbate, enzyme extract and $0.1 \mathrm{mM} \mathrm{H}_{2} \mathrm{O}_{2}$ as the reaction initiator. The absorbance changes were read within $3 \mathrm{~min}$ at the $290 \mathrm{~nm}$ wavelength (extinction coefficient of ascorbate $=2.8 \mathrm{mM}^{-1} \cdot \mathrm{cm}^{-1}$ ) using Hitachi Spectrophotometer. The enzyme specific activity was expressed as $\mu \mathrm{mol}$ of ascorbate oxidised $\mathrm{mg}$ protein ${ }^{-1} \cdot \mathrm{min}^{-1}$.

CAT activity was assayed according to Beers and Sizer (1952). The assay mixture $\left(3 \mathrm{~cm}^{3}\right)$ contained $100 \mathrm{mM}$ phosphate buffer ( $\mathrm{pH} 7.5), 200 \mathrm{mM} \mathrm{H}_{2} \mathrm{O}_{2}$ and enzyme extract. The absorbance changes were observed at $45 \mathrm{~s}$ and $60 \mathrm{~s}$ after the adding of enzyme extract to assay mixture (wavelength was $240 \mathrm{~nm}$, extinction coefficient of hydrogen peroxide $=39.4 \mathrm{mM}^{-1} \cdot \mathrm{cm}^{-1}$ ). 
The enzyme specific activity was expressed as $\mu \mathrm{mol}$ of $\mathrm{H}_{2} \mathrm{O}_{2}$ oxidised $\mathrm{mg}$ protein ${ }^{-1} \cdot \mathrm{min}^{-1}$.

Assay mixture for POX in a total volume $2 \mathrm{~cm}^{3}$ consisted of $15 \mathrm{mM}$ phosphate buffer ( $\mathrm{pH}$ 6.5), $10 \mathrm{mM}$ guaiacol (o-methoxyphenol), enzyme extract and $1 \mathrm{mM}$ $\mathrm{H}_{2} \mathrm{O}_{2}$ as a reaction initiator. The changes of absorbance were determined for $3 \mathrm{~min}$ at $470 \mathrm{~nm}$ (extinction coefficient of guaiacol $=26.6 \mathrm{mM}^{-1} \cdot \mathrm{cm}^{-1}$ ). The POX activity was expressed as $\mu \mathrm{mol}$ of guaiacol oxidised $\mathrm{mg} \cdot$ protein $^{-1} \cdot \mathrm{min}^{-1}$ (Reuveni et al., 1992).

The total protein content in all leaves extracts was analysed by Lowry method with bovine serum albumin as a standard (Waterborg, 2002).

\section{Sugar content analysis}

The glucose, fructose and sucrose content was analysed in extracts prepared for CAT and POX activity analysis. Measurements were conducted by Beckman PA 800 Plus capillary electrophoresis (CE) with DAD detection. The following parameters for analysis were applied: capillary of $\varnothing 25 \mu \mathrm{m}$ and the total length of $60.5 \mathrm{~cm}$
(50 $\mathrm{cm}$ to the detector), the positive power supply of $30 \mathrm{kV}$ and temperature of detection $18^{\circ} \mathrm{C}$. The running buffer solution consisted of $3.6 \mathrm{mM} \mathrm{Na} \mathrm{HPO}_{4}$ and $0.2 \mathrm{mM} \beta$-cyclodextrin. The $\mathrm{pH}$ of the buffer solution was set to 12.7 using $130 \mathrm{mM} \mathrm{NaOH}$. The sum of the contents of glucose, fructose and sucrose was presented as the total sugar content (Smoleń et al., 2016).

\section{Statistical analysis}

All data were statistically verified using ANOVA module of Statistica 12.0 PL program at significance level $p<0.05$. In the case of significant changes, homogenous mean groups were distinguished based on the Tukey test.

\section{RESULTS}

\section{Biomass of tomato seedlings}

In general, the application of BeA did not affect the weight of leaves, stems and roots (Table 1 and Figure 1C). Only in the case of $25 \mu \mathrm{M}$ dose, a slight increase of root and

Table 1. Fresh weight of leaves, stems and roots per one tomato plant after tested compounds treatment

\begin{tabular}{|c|c|c|c|}
\hline Treatment & $\begin{array}{l}\text { Weight of leaves per one plant } \\
\qquad(\mathrm{g}) \pm \mathrm{SE}\end{array}$ & $\begin{array}{l}\text { Weight of stems per one plant } \\
\qquad(\mathrm{g}) \pm \mathrm{SE}\end{array}$ & $\begin{array}{l}\text { Weight of roots per one plant } \\
\qquad(\mathrm{g}) \pm \mathrm{SE}\end{array}$ \\
\hline Control & $0.90 \pm 0.08 \mathrm{a}$ & $1.10 \pm 0.05 \mathrm{a}$ & $0.34 \pm 0.04 \mathrm{a}$ \\
\hline Control + ethanol & $1.23 \pm 0.04 \mathrm{~b}$ & $1.00 \pm 0.03 \mathrm{a}$ & $0.48 \pm 0.01 \mathrm{~b}$ \\
\hline $\mathrm{BeA}(5 \mu \mathrm{M})$ & $1.04 \pm 0.04 \mathrm{ab}$ & $1.00 \pm 0.03 \mathrm{a}$ & $0.39 \pm 0.02 \mathrm{ab}$ \\
\hline $\mathrm{BeA}(10 \mu \mathrm{M})$ & $1.11 \pm 0.03 \mathrm{ab}$ & $1.09 \pm 0.05 \mathrm{a}$ & $0.40 \pm 0.03 \mathrm{ab}$ \\
\hline $\mathrm{BeA}(25 \mu \mathrm{M})$ & $1.20 \pm 0.08 \mathrm{~b}$ & $1.17 \pm 0.06 \mathrm{a}$ & $0.48 \pm 0.05 \mathrm{~b}$ \\
\hline $\mathrm{BeA}(50 \mu \mathrm{M})$ & $1.05 \pm 0.02 \mathrm{ab}$ & $1.06 \pm 0.07 \mathrm{a}$ & $0.42 \pm 0.01 \mathrm{ab}$ \\
\hline Control & $0.90 \pm 0.07 \mathrm{a}$ & $1.10 \pm 0.05 \mathrm{a}$ & $0.34 \pm 0.05 \mathrm{a}$ \\
\hline Control + ethanol & $1.23 \pm 0.03 b$ & $0.99 \pm 0.03 \mathrm{a}$ & $0.49 \pm 0.02 b$ \\
\hline $\mathrm{KI}(5 \mu \mathrm{M} \mathrm{I})$ & $1.01 \pm 0.09 \mathrm{ab}$ & $1.09 \pm 0.10 \mathrm{a}$ & $0.33 \pm 0.03 \mathrm{a}$ \\
\hline $\mathrm{KI}(10 \mu \mathrm{M} \mathrm{I})$ & $1.11 \pm 0.08 \mathrm{ab}$ & $1.18 \pm 0.03 \mathrm{a}$ & $0.36 \pm 0.02 \mathrm{ab}$ \\
\hline $\mathrm{KI}(25 \mu \mathrm{M} \mathrm{I})$ & $1.11 \pm 0.05 \mathrm{ab}$ & $1.24 \pm 0.02 \mathrm{a}$ & $0.42 \pm 0.01 \mathrm{ab}$ \\
\hline $\mathrm{KI}(50 \mu \mathrm{M} \mathrm{I})$ & $1.05 \pm 0.06 \mathrm{ab}$ & $1.17 \pm 0.06 \mathrm{a}$ & $0.37 \pm 0.04 \mathrm{ab}$ \\
\hline Control & $0.90 \pm 0.07 \mathrm{a}$ & $1.10 \pm 0.06 \mathrm{a}$ & $0.34 \pm 0.06 \mathrm{a}$ \\
\hline Control + ethanol & $1.23 \pm 0.04 \mathrm{~b}$ & $1.00 \pm 0.04 \mathrm{a}$ & $0.48 \pm 0.02 \mathrm{ab}$ \\
\hline 2-IBeA $(5 \mu \mathrm{M} \mathrm{I})$ & $1.37 \pm 0.04 \mathrm{~b}$ & $1.34 \pm 0.04 \mathrm{~b}$ & $0.66 \pm 0.05 \mathrm{~b}$ \\
\hline 2-IBeA $(10 \mu \mathrm{M} \mathrm{I})$ & $1.22 \pm 0.08 \mathrm{~b}$ & $1.38 \pm 0.07 \mathrm{~b}$ & $0.52 \pm 0.06 \mathrm{~b}$ \\
\hline 2-IBeA $(25 \mu \mathrm{M} \mathrm{I})$ & $1.28 \pm 0.08 \mathrm{~b}$ & $1.46 \pm 0.06 \mathrm{~b}$ & $0.55 \pm 0.04 \mathrm{~b}$ \\
\hline 2-IBeA $(50 \mu \mathrm{M} \mathrm{I})$ & $1.32 \pm 0.03 \mathrm{~b}$ & $1.50 \pm 0.03 \mathrm{~b}$ & $0.61 \pm 0.06 \mathrm{~b}$ \\
\hline Control & $0.91 \pm 0.07 \mathrm{~b}$ & $1.11 \pm 0.05 \mathrm{c}$ & $0.34 \pm 0.06 \mathrm{c}$ \\
\hline Control + ethanol & $1.23 \pm 0.05 \mathrm{~b}$ & $1.01 \pm 0.04 \mathrm{c}$ & $0.48 \pm 0.01 \mathrm{~b}$ \\
\hline 4-IBeA $(5 \mu \mathrm{M} \mathrm{I})$ & $0.94 \pm 0.04 \mathrm{~b}$ & $0.67 \pm 0.04 \mathrm{bc}$ & $0.51 \pm 0.03 \mathrm{bc}$ \\
\hline 4-IBeA (10 $\mu \mathrm{M} \mathrm{I})$ & $0.42 \pm 0.19 \mathrm{a}$ & $0.29 \pm 0.12 \mathrm{ab}$ & $0.37 \pm 0.14 b$ \\
\hline 4-IBeA (25 $\mu \mathrm{M} \mathrm{I})$ & $0.10 \pm 0.02 \mathrm{a}$ & $0.05 \pm 0.01 \mathrm{a}$ & $0.09 \pm 0.03 \mathrm{a}$ \\
\hline 4-IBeA $(50 \mu \mathrm{M} \mathrm{I})$ & $0.07 \pm 0.01 \mathrm{a}$ & $0.03 \pm 0.01 \mathrm{a}$ & $0.08 \pm 0.02 \mathrm{a}$ \\
\hline Control & $0.91 \pm 0.08 \mathrm{a}$ & $1.11 \pm 0.06 \mathrm{a}$ & $0.34 \pm 0.05 \mathrm{a}$ \\
\hline Control + ethanol & $1.24 \pm 0.06 \mathrm{~b}$ & $1.00 \pm 0.03 \mathrm{a}$ & $0.47 \pm 0.01 \mathrm{ab}$ \\
\hline 2,3,5-triIBeA $(5 \mu \mathrm{M} \mathrm{I})$ & $1.50 \pm 0.06 \mathrm{~d}$ & $1.35 \pm 0.06 \mathrm{c}$ & $0.61 \pm 0.04 \mathrm{~b}$ \\
\hline 2,3,5-triIBeA $(10 \mu \mathrm{M} \mathrm{I})$ & $1.38 \pm 0.04 \mathrm{c}$ & $1.23 \pm 0.04 \mathrm{ab}$ & $0.46 \pm 0.05 \mathrm{ab}$ \\
\hline 2,3,5-triIBeA $(25 \mu \mathrm{M} \mathrm{I})$ & $1.32 \pm 0.09 \mathrm{~b}$ & $1.18 \pm 0.02 \mathrm{ab}$ & $0.45 \pm 0.02 \mathrm{ab}$ \\
\hline 2,3,5-triIBeA $(50 \mu \mathrm{M} \mathrm{I})$ & $1.08 \pm 0.06 \mathrm{ab}$ & $1.13 \pm 0.08 \mathrm{ab}$ & $0.35 \pm 0.03 \mathrm{a}$ \\
\hline
\end{tabular}

Means followed by the same letters are not significantly different for $p<0.05$.

Statistical analysis was conducted for each part of tomato plants separately $(n=8)$. 


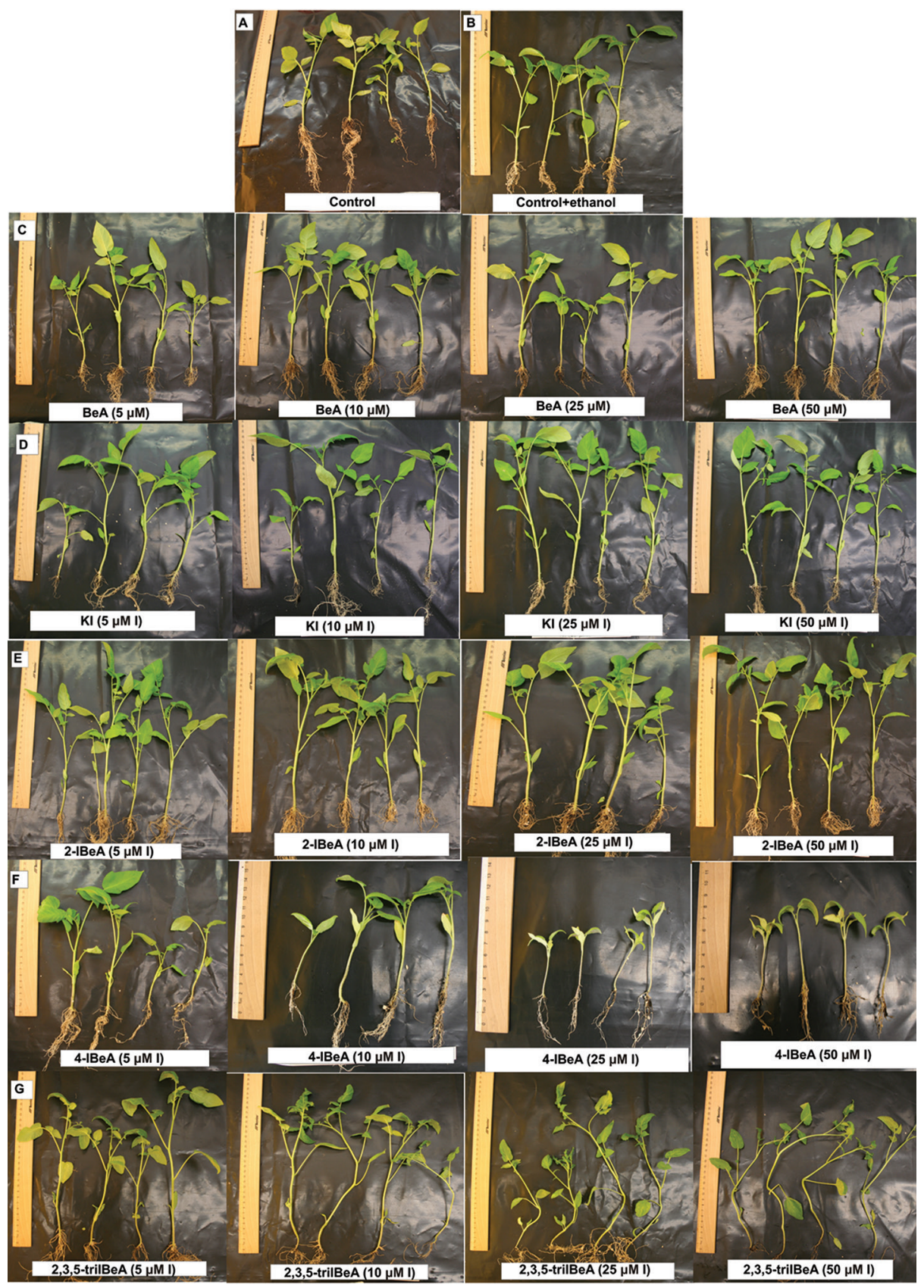

Figure 1. The phenotype of young tomato plants from the control (A), control + ethanol (B) BeA (C), KI (D), 2-IBeA (E), 4-IBeA (F) and 2,3,5-triIBeA (G) treatment.

leaf biomass was observed. The application of a mineral form of iodine as KI did not influence the biomass of leaves, stems and roots of tomato seedlings (Table 1 and Figure 1D). Plant biomass was significantly higher after 2-IBeA application at all concentrations (Table 1 and Figure 1E).

The negative effect of 4-IBeA treatment on plant growth was observed at concentrations $10 \mu \mathrm{M}$ I, $25 \mu \mathrm{M} \mathrm{I}$ and $50 \mu \mathrm{M}$ I (Figure 1F). The decrease of biomass in these treatments as compared to control plants (Figure 1A, Figure 1B) was 53\%, 89\% and $92 \%$, respectively, for leaves and $74 \%, 95 \%$ and $97 \%$ for stems. The lowest root biomass was observed for $25 \mu \mathrm{M}$ I and $50 \mu \mathrm{M}$ I doses of 4-IBeA.
Application of 2,3,5-triIBeA at $5 \mu \mathrm{M} \mathrm{I}, 10 \mu \mathrm{M}$ I and $25 \mu \mathrm{M}$ I doses contributed to a significant increase in leaf biomass. However, root and stem biomass of tomato was improved only when the lowest concentration of that compound was applied $(5 \mu \mathrm{M}$ I). The plants grown in the presence of 2,3,5-triIBeA at $10 \mu \mathrm{M} \mathrm{I}, 25 \mu \mathrm{M}$ I and $50 \mu \mathrm{M}$ I doses were twisted and elongated (Figure $1 \mathrm{G}$ ).

Compared to control, treatment with ethanol improved leaf and root biomass (Table 1).

\section{Iodine content in different parts of the plant}

The application of iodine as inorganic and organic compounds increased iodine accumulation in leaves, stems and roots of tomato seedlings (Table 2). Iodine 
content in individual parts of the plant tends to increase with increasing iodine dosage with the highest value obtained for $50 \mu \mathrm{M}$ I application. The trace of iodine present in the water or as fertiliser contaminants contributed to obtaining the level of $\approx 0.4 \mathrm{mg} \mathrm{I} \cdot \mathrm{kg}^{-1}$ d.w. in leaves, stems and roots of control and control + ethanol plants (Table 2). After the application of BeA, iodine content was more or less at the level of control plants.

The iodine applied as KI was evenly distributed in the leaves, stems and roots, but for organic forms, except for 4 -IBeA at doses of $25 \mu \mathrm{M}$ I and $50 \mu \mathrm{M}$ I, it was mainly accumulated in roots (Table 2). The greatest retention of iodine in roots was noted in plants grown in the presence of $50 \mu \mathrm{M}$ I of 2 -IBeA. The noted iodine content in roots from that combination was three times higher than for KI, two times higher than for 4-IBeA and six times higher than for 2,3,5-triIBeA applied in the same dose (Table 2). The more efficient transport of iodine to the upper parts of tomato seedlings (leaves and stems) was noted for 4-IBeA than 2-IBeA (Table 2). The lowest iodine content in tomato seedlings was observed after 2,3,5-triIBeA application and its values were in the range from 30.4 to $45.7 \mathrm{mg}$ $\mathrm{I} \cdot \mathrm{kg}^{-1}$ d.w. for leaves; from 26.0 to $65.1 \mathrm{mg} \mathrm{I} \cdot \mathrm{kg}^{-1}$ d.w. for stems and from 43.2 to $257.6 \mathrm{mg} \mathrm{I} \cdot \mathrm{kg}^{-1}$ d.w. for roots, respectively, for the lowest and highest dose of 2,3,5-trilBeA (Table 2). The iodine content in leaves ranged from 52.5 to $548.8 \mathrm{mg} \mathrm{I} \cdot \mathrm{kg}^{-1}$ d.w. for KI application; from 19.2 to $49.1 \mathrm{mg} \mathrm{I} \cdot \mathrm{kg}^{-1} \mathrm{~d}$.w. for 2-IBeA and from 21.3 to $122.2 \mathrm{mg} \mathrm{I} \cdot \mathrm{kg}^{-1}$ d.w. for $4-\mathrm{IBeA}$ treatment, respectively, for the lowest and highest dose of KI, 2-IBeA and 4-IBeA (Table 2). The iodine content in tomato roots ranged from 54.2 to $449.2 \mathrm{mg} \mathrm{I} \cdot \mathrm{kg}^{-1}$ d.w. for KI; from 26.2 to $122.5 \mathrm{mg} \mathrm{I} \cdot \mathrm{kg}^{-1}$ d.w. for 2-IBeA and from 73.9 to $668.3 \mathrm{mg} \mathrm{I} \cdot \mathrm{kg}^{-1} \mathrm{~d}$.w. for 4 -IBeA applications.

\section{Ascorbic and dehydroascorbic acid content in leaves}

The tested compounds had a significant effect on AA and DHA level in leaves of tomato seedlings (Figures 2 and 3). The analysis of AA and DHA content for 4-IBeA treatment at a dose of $10 \mu \mathrm{M}$ I, $25 \mu \mathrm{M}$ I and $50 \mu \mathrm{M}$ I was not performed due to the insufficient amount of

Table 2. Iodine content in leaves, stems and roots of young tomato plants after BeA (A), KI (B), 2-IBeA (C), 4-IBeA (D) and 2,3,5-trilBeA treatment

\begin{tabular}{|c|c|c|c|}
\hline Treatments & Leaves $\left(\mathrm{mg} \mathrm{I} \cdot \mathrm{kg}^{-1}\right.$ d.w. $) \pm \mathrm{SE}$ & Stems $\left(\mathrm{mg} \mathrm{I} \cdot \mathrm{kg}^{-1}\right.$ d.w. $) \pm \mathrm{SE}$ & Roots (mg I $\cdot \mathrm{kg}^{-1}$ d.w.) $\pm \mathrm{SE}$ \\
\hline Control & $0.32 \pm 0.07 \mathrm{a}$ & $0.45 \pm 0.05 \mathrm{a}$ & $0.24 \pm 0.03 \mathrm{a}$ \\
\hline Control + ethanol & $0.51 \pm 0.11 \mathrm{ab}$ & $0.41 \pm 0.01 \mathrm{a}$ & $0.29 \pm 0.05 \mathrm{a}$ \\
\hline $\mathrm{BeA}(5 \mu \mathrm{mol})$ & $0.58 \pm 0.10 \mathrm{ab}$ & $0.64 \pm 0.03 \mathrm{~b}$ & $0.29 \pm 0.03 \mathrm{a}$ \\
\hline $\mathrm{BeA}(10 \mu \mathrm{mol})$ & $0.60 \pm 0.14 \mathrm{ab}$ & $0.65 \pm 0.05 \mathrm{~b}$ & $0.24 \pm 0.01 \mathrm{a}$ \\
\hline $\mathrm{BeA}(25 \mu \mathrm{mol})$ & $0.43 \pm 0.12 \mathrm{ab}$ & $0.43 \pm 0.03 \mathrm{a}$ & $0.27 \pm 0.03 \mathrm{a}$ \\
\hline $\mathrm{BeA}(50 \mu \mathrm{mol})$ & $0.86 \pm 0.08 \mathrm{~b}$ & $0.55 \pm 0.03 \mathrm{ab}$ & $0.28 \pm 0.05 \mathrm{a}$ \\
\hline Control & $0.32 \pm 0.06 \mathrm{a}$ & $0.45 \pm 0.05 \mathrm{a}$ & $0.23 \pm 0.04 \mathrm{a}$ \\
\hline Control + ethanol & $0.50 \pm 0.11 \mathrm{a}$ & $0.41 \pm 0.02 \mathrm{a}$ & $0.29 \pm 0.05 \mathrm{a}$ \\
\hline $\mathrm{KI}(5 \mu \mathrm{M} \mathrm{I})$ & $52.49 \pm 0.57 \mathrm{~b}$ & $127.91 \pm 1.33 \mathrm{~b}$ & $54.20 \pm 1.72 b$ \\
\hline $\mathrm{KI}(10 \mu \mathrm{M} \mathrm{I})$ & $86.97 \pm 2.00 \mathrm{c}$ & $234.15 \pm 3.96 \mathrm{c}$ & $173.28 \pm 3.47 \mathrm{c}$ \\
\hline $\mathrm{KI}(25 \mu \mathrm{M} \mathrm{I})$ & $238.98 \pm 4.66 \mathrm{~d}$ & $530.86 \pm 9.37 \mathrm{~d}$ & $307.87 \pm 3.61 \mathrm{~d}$ \\
\hline $\mathrm{KI}(50 \mu \mathrm{M} \mathrm{I})$ & $548.76 \pm 12.57 \mathrm{e}$ & $1023.90 \pm 10.29 \mathrm{e}$ & $449.16 \pm 5.35 \mathrm{e}$ \\
\hline Control & $0.32 \pm 0.07 \mathrm{a}$ & $0.45 \pm 0.06 \mathrm{a}$ & $0.24 \pm 0.02 \mathrm{a}$ \\
\hline Control + ethanol & $0.50 \pm 0.11 \mathrm{a}$ & $0.41 \pm 0.01 \mathrm{a}$ & $0.28 \pm 0.06 \mathrm{a}$ \\
\hline 2-IBeA $(5 \mu \mathrm{M} \mathrm{I})$ & $19.18 \pm 0.60 \mathrm{~b}$ & $26.18 \pm 2.84 b$ & $116.97 \pm 1.93 \mathrm{~b}$ \\
\hline 2-IBeA $(10 \mu \mathrm{M} \mathrm{I})$ & $31.72 \pm 1.65 \mathrm{c}$ & $49.51 \pm 2.91 \mathrm{c}$ & $266.72 \pm 6.57 \mathrm{c}$ \\
\hline 2-IBeA $(25 \mu \mathrm{M} \mathrm{I})$ & $49.10 \pm 2.23 \mathrm{~d}$ & $99.74 \pm 1.52 \mathrm{~d}$ & $685.92 \pm 4.79 \mathrm{~d}$ \\
\hline 2-IBeA $(50 \mu \mathrm{M} \mathrm{I})$ & $39.86 \pm 5.21 \mathrm{~d}$ & $122.51 \pm 4.12 \mathrm{e}$ & $1464.37 \pm 33.59 \mathrm{e}$ \\
\hline Control & $0.33 \pm 0.07 \mathrm{a}$ & $0.46 \pm 0.05 \mathrm{a}$ & $0.24 \pm 0.03 \mathrm{a}$ \\
\hline Control + ethanol & $0.51 \pm 0.12 \mathrm{a}$ & $0.40 \pm 0.02 \mathrm{a}$ & $0.29 \pm 0.05 \mathrm{a}$ \\
\hline 4-IBeA $(5 \mu \mathrm{M} \mathrm{I})$ & $21.31 \pm 2.48 b$ & $38.59 \pm 2.98 b$ & $73.89 \pm 1.46 b$ \\
\hline 4-IBeA $(10 \mu \mathrm{M} \mathrm{I})$ & $62.38 \pm 0.54 \mathrm{c}$ & $158.18 \pm 9.07 \mathrm{c}$ & $161.27 \pm 2.58 \mathrm{c}$ \\
\hline 4-IBeA $(25 \mu \mathrm{M} \mathrm{I})$ & $122.21 \pm 7.10 \mathrm{~d}$ & $643.17 \pm 34.67 \mathrm{~d}$ & $335.62 \pm 6.01 \mathrm{~d}$ \\
\hline 4-IBeA $(50 \mu \mathrm{M} \mathrm{I})$ & $114.00 \pm 10.31 \mathrm{~d}$ & $769.52 \pm 21.80 \mathrm{e}$ & $668.33 \pm 36.29 \mathrm{e}$ \\
\hline Control & $0.32 \pm 0.07 \mathrm{a}$ & $0.46 \pm 0.04 \mathrm{a}$ & $0.25 \pm 0.04 \mathrm{a}$ \\
\hline Control + ethanol & $0.51 \pm 0.11 \mathrm{a}$ & $0.41 \pm 0.02 \mathrm{a}$ & $0.29 \pm 0.04 \mathrm{a}$ \\
\hline 2,3,5-triIBeA $(5 \mu \mathrm{M} \mathrm{I})$ & $36.11 \pm 0.57 b$ & $25.98 \pm 0.67 b$ & $43.21 \pm 1.94 b$ \\
\hline 2,3,5-triIBeA $(10 \mu \mathrm{M} \mathrm{I})$ & $45.72 \pm 3.07 \mathrm{c}$ & $29.08 \pm 0.98 b$ & $81.07 \pm 3.32 \mathrm{c}$ \\
\hline $2,3,5$-triIBeA $(25 \mu \mathrm{M} \mathrm{I})$ & $30.44 \pm 0.22 b$ & $52.11 \pm 1.75 \mathrm{c}$ & $192.26 \pm 1.57 \mathrm{~d}$ \\
\hline $2,3,5$-triIBeA $(50 \mu \mathrm{M} \mathrm{I})$ & $35.38 \pm 1.79 \mathrm{~b}$ & $65.13 \pm 1.59 \mathrm{~d}$ & $257.60 \pm 13.70 \mathrm{e}$ \\
\hline
\end{tabular}

Means followed by the same letters are not significantly different for $p<0.05$.

Statistical analysis was conducted for each part of tomato plants separately $(n=8)$. 
A

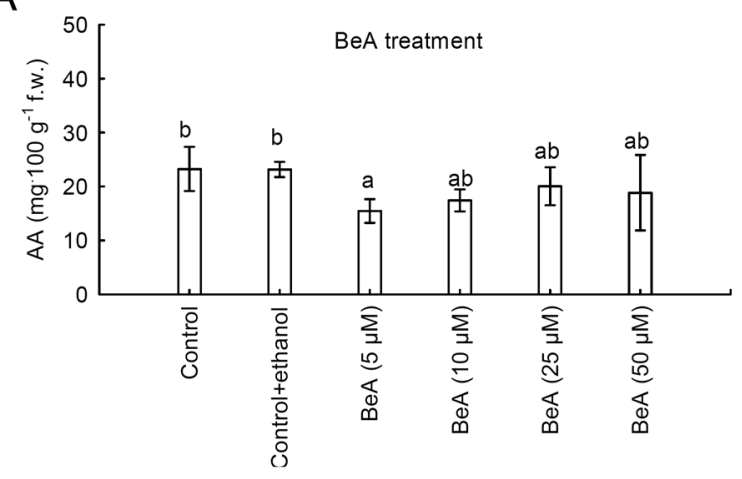

C

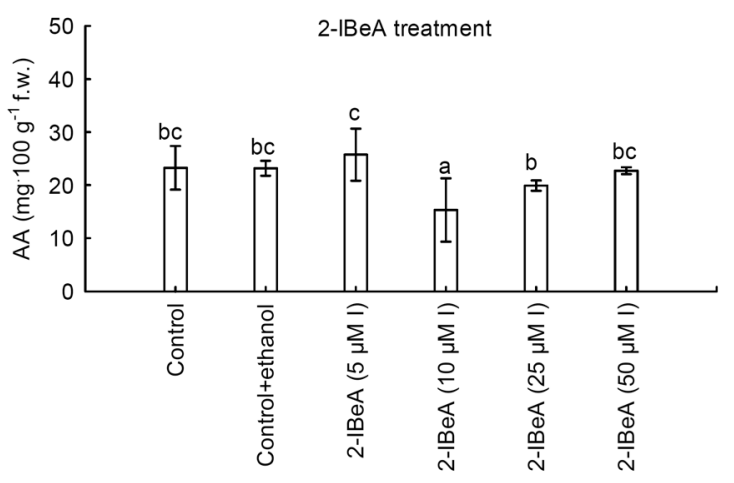

B

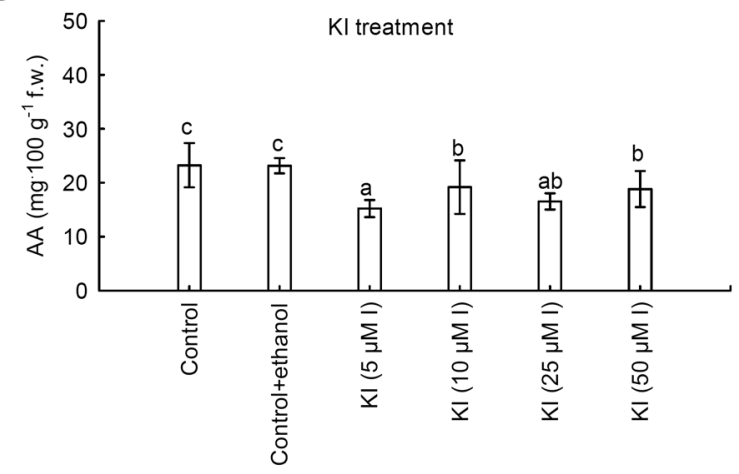

D

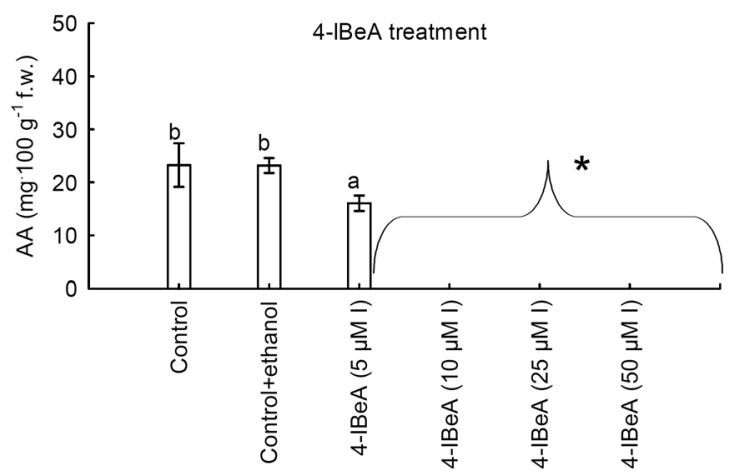

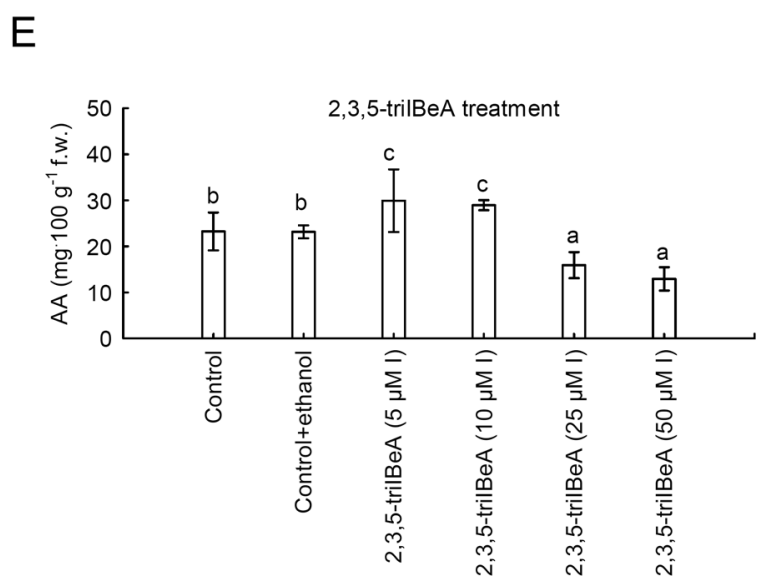

Figure 2. AA content in leaves of young tomato plants after BeA (A), KI (B), 2-IBeA (C), 4-IBeA(D) and 2,3,5-triIBeA (E) treatments. Means followed by the same letters are not significantly different for $p<0.05$. Bars indicate standard error $(n=8)$. * The analysis was not done due to the lack of plant material due to the low yield in 4-IBeA treatment in $10 \mu \mathrm{M} \mathrm{I}, 25 \mu \mathrm{M}$ I and $50 \mu \mathrm{M}$ I concentration (see Table 1).

available plant material resulting from the low yield obtained in these combinations (see Table 1).

In all combinations, the level of AA was around 10 times higher than the DHA content (Figures 2 and 3). The application of BeA, KI and 4-IBeA at a dose of 5 $\mu \mathrm{M}$ I reduced AA content (Figures 2A, 2B and 2D) but did not affect DHA content in leaves (Figures 3A, 3B and 3D). The BeA application at higher doses had no significant influence on AA and DHA level (Figures $2 \mathrm{~A}$ and $3 \mathrm{~A}$ ) with the only exception of $25 \mu \mathrm{M}$ I dose that contributed to a 2.5-times increase of DHA content in leaves as compared to control plants (Figure 3A). After
$\mathrm{KI}$ application at all doses, the decrease of AA content was observed (Figure 2B). However, the application of $10 \mu \mathrm{M} \mathrm{I}$ as KI increased DHA content in tomato leaves - the remaining KI doses did not significantly modify DHA content in the leaves (Figure 3B). The 2-IBeA treatment at a dose of $5 \mu \mathrm{M}$ I and 2,3,5-triIBeA at doses of $5 \mu \mathrm{M}$ I and $10 \mu \mathrm{M}$ I caused a respective $10.3 \%, 28.3 \%$ and $24 \%$ increase of AA content as compared to the control plants (Figures $2 \mathrm{C}$ and $2 \mathrm{E}$ ). The application of 2,3,5-triIBeA at doses of $25 \mu \mathrm{M} \mathrm{I}$ and $50 \mu \mathrm{M} \mathrm{I}$ led to $31.3 \%$ and $44.2 \%$ decrease of AA content in leaves. In the case of DHA, its content was 
A

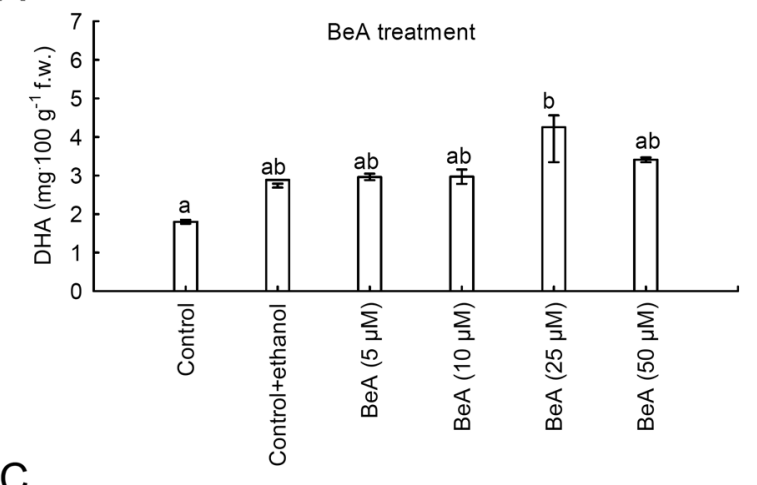

C

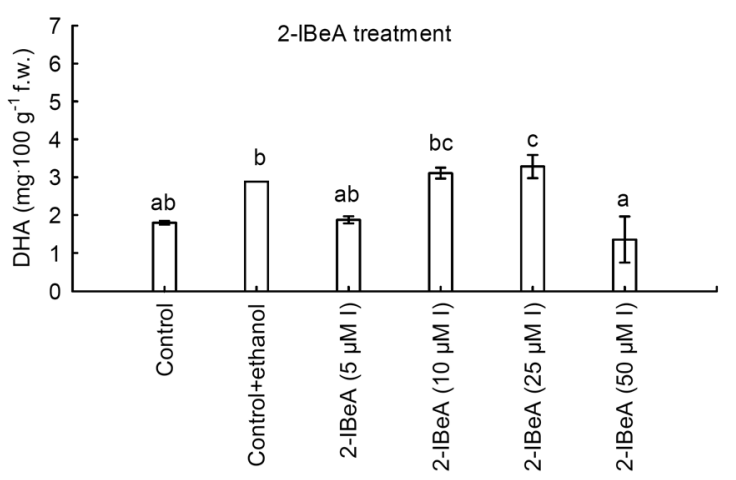

B

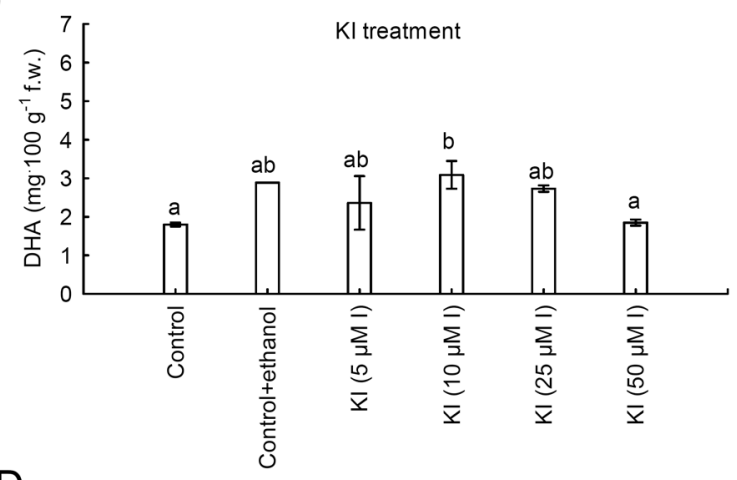

$\mathrm{D}$

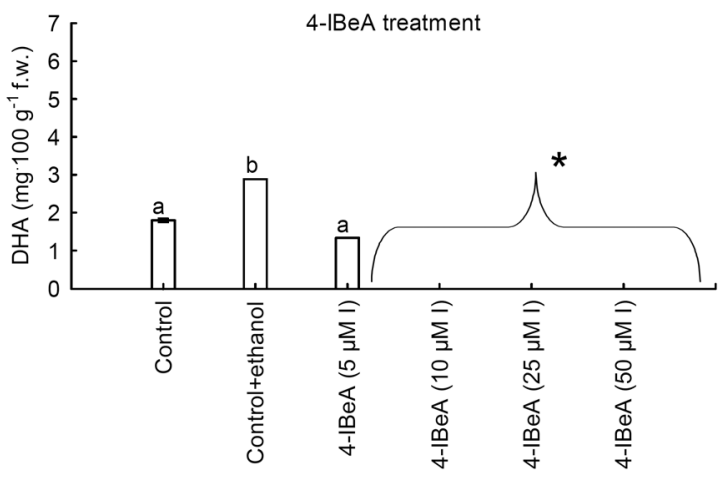

$\mathrm{E}$

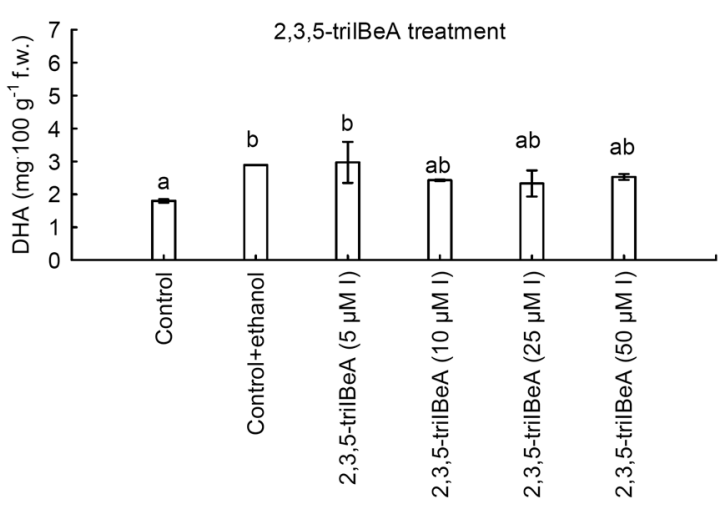

Figure 3. DHA content in leaves of young tomato plants after BeA(A), KI (B), 2-IBeA(C), 4-IBeA(D) and 2,3,5-trilBeA (E) treatments. Means followed by the same letters are not significantly different for $p<0.05$. Bars indicate standard error $(n=8) .{ }^{*}$ The analysis was not done due to the lack of plant material due to the low yield in 4-IBeA treatment in $10 \mu \mathrm{M} \mathrm{I}, 25 \mu \mathrm{M}$ I and $50 \mu \mathrm{M}$ I concentration (see Table 1).

positively affected by 2,3,5-triBeA only at a dose of $5 \mu \mathrm{M}$ I (Figure 3E).

\section{Enzyme activity}

The activity of the tested antioxidant enzymes APX, CAT and POX in tomato leaves was differential and dependent on the form and concentration of applied iodine compounds.

Compared to the control, the application of $\mathrm{BeA}$ did not influence APX activity in leaves (Figure 4A). The significant increase of APX activity was noted after KI treatment at the highest doses 25 and 50 $\mu \mathrm{M} \mathrm{I}$ and was, respectively, 1.5 times and 1.6 times higher compared to the control plants (Figure 4B). The application of lower doses of KI, i.e., $5 \mu \mathrm{M}$ I and $10 \mu \mathrm{M} \mathrm{I}$, led to 3.8 times and 1.8 times decrease of APX activity in leaves of tomato seedlings. All tested iodobenzoates had a decreasing effect on APX activity (Figures 4C-4E).

The CAT activity was not significantly modified (compared to the control plants) by BeA treatment at a dose of $5 \mu \mathrm{M} \mathrm{I}, 25 \mu \mathrm{M}$ I and $50 \mu \mathrm{M} \mathrm{I}$ (Figure 5A) and $\mathrm{KI}$ application at a dose of $5 \mu \mathrm{M} \mathrm{I}, 10 \mu \mathrm{M} \mathrm{I}$ and $50 \mu \mathrm{M} \mathrm{I}$ (Figure 5B). The BeA treatment at a dose of $10 \mu \mathrm{M}$ I and $\mathrm{KI}$ at a dose of $25 \mu \mathrm{M}$ I caused a slight reduction of CAT activity, respectively, by $12.8 \%$ and $25.5 \%$, as compared 
A
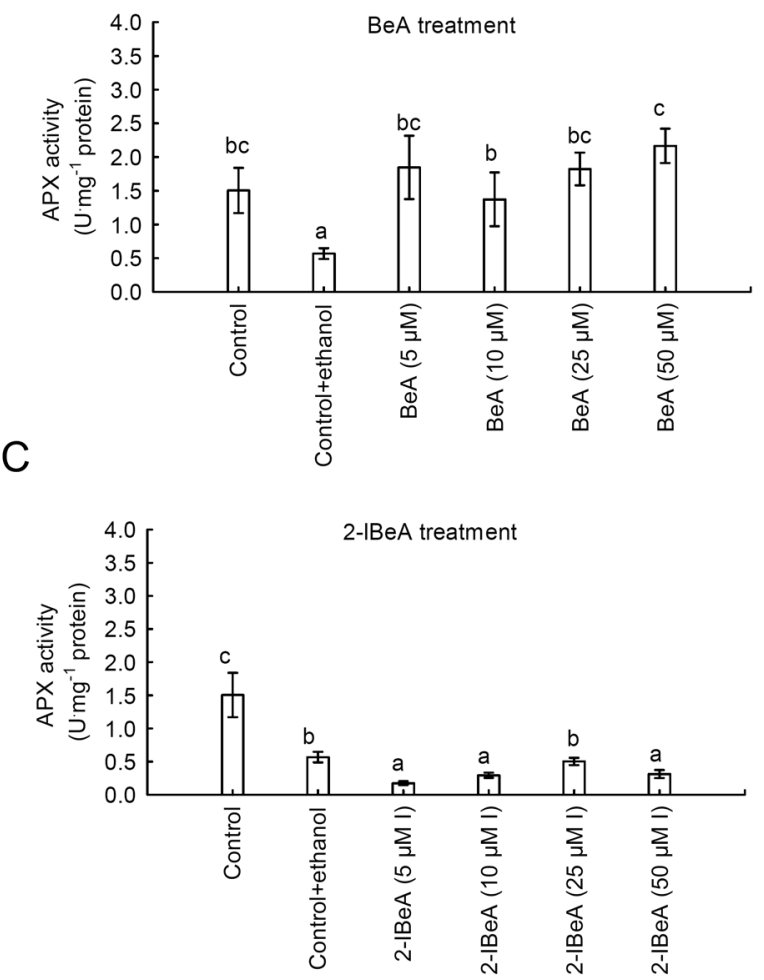

B
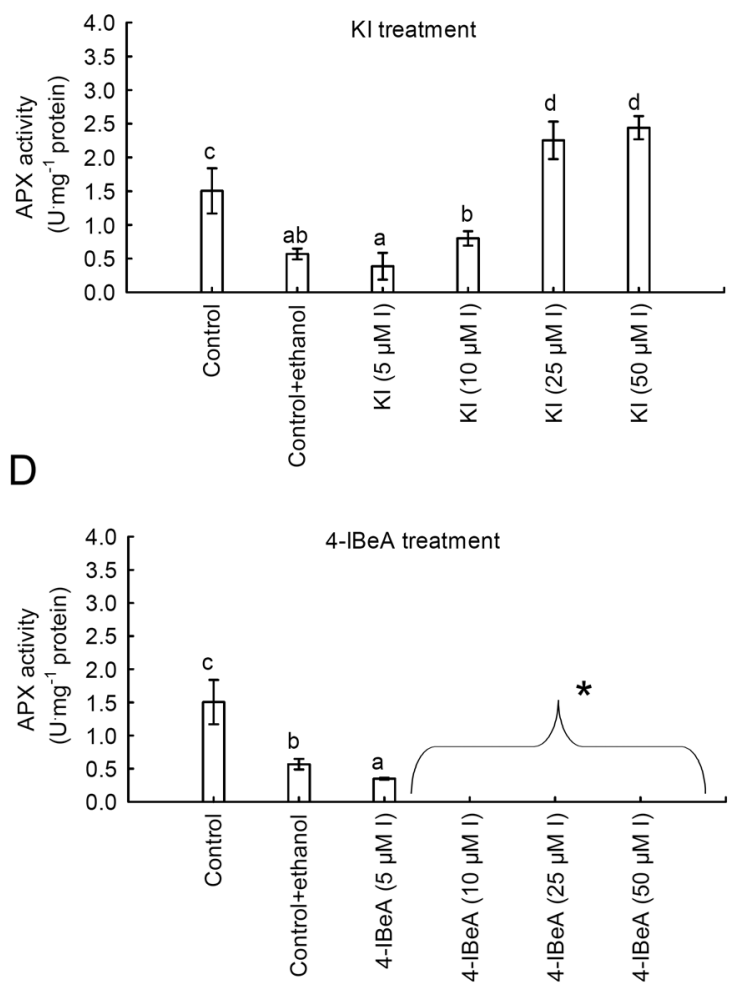

\section{$E$}

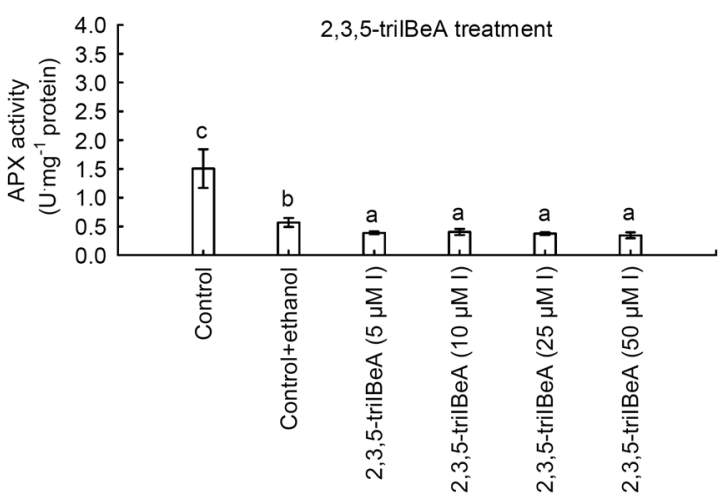

Figure 4. APX activity in leaves of young tomato plants after BeA(A), KI (B), 2-IBeA(C), 4-IBeA(D) and 2,3,5-triIBeA (E) treatments. Means followed by the same letters are not significantly different for $p<0.05$. Bars indicate standard error $(n=8) . *$ The analysis was not done due to the lack of plant material due to the low yield in 4-IBeA treatment in $10 \mu \mathrm{M} \mathrm{I}, 25 \mu \mathrm{M}$ I and $50 \mu \mathrm{M}$ I concentration (see Table 1).

to control plants (Figures 5A and 5B). The application of 2-IBeA, 4-IBeA and 2,3,5-triIBeA significantly decreased CAT activity, on average by $87 \%$ for 2 -IBeA and 2,3,5-triIBeA as well as $\approx 89 \%$ for 4 -IBeA at a dose of $5 \mu \mathrm{M}$ I compared to control plants (Figures $5 \mathrm{C}-5 \mathrm{E}$ ). The CAT activity in control + ethanol plants was at the same level as after 2-IBeA, 4-IBeA and 2,3,5-triIBeA treatments (Figure 5).

Application of all doses of BeA caused a significant reduction of POX activity in tomato leaves (Figure $6 \mathrm{~A})$. The highest decrease was observed for the dose of $10 \mu \mathrm{M}$ and in that combination POX activity was $57.1 \%$ lower than for control plants. The KI treatment with $50 \mu \mathrm{M}$ I dose did not influence POX activity (Figure 6B). The lower concentrations (5 $\mu \mathrm{M} \mathrm{I}, 10 \mu \mathrm{M}$ I and $25 \mu \mathrm{M} \mathrm{I}$ ) of $\mathrm{KI}$ and all concentrations of 2-IBeA significantly reduced POX activity in tomato leaves (Figures 6B and 6C).

The 4-IBeA at a dose of $5 \mu \mathrm{M}$ I led to 1.7 times increase of POX activity compared to control plants (Figure 6D). The addition of 2,3,5-trIBeA to the nutrient solution at lower doses, i.e., $5 \mu \mathrm{M}$ I and 10 $\mu \mathrm{M} I$, had no significant influence on POX activity. However, for the concentrations of $25 \mu \mathrm{M} \mathrm{I}$ and 50 $\mu \mathrm{M}$ I the 1.4 times increase of POX activity was noted (Figure 6E). 
A

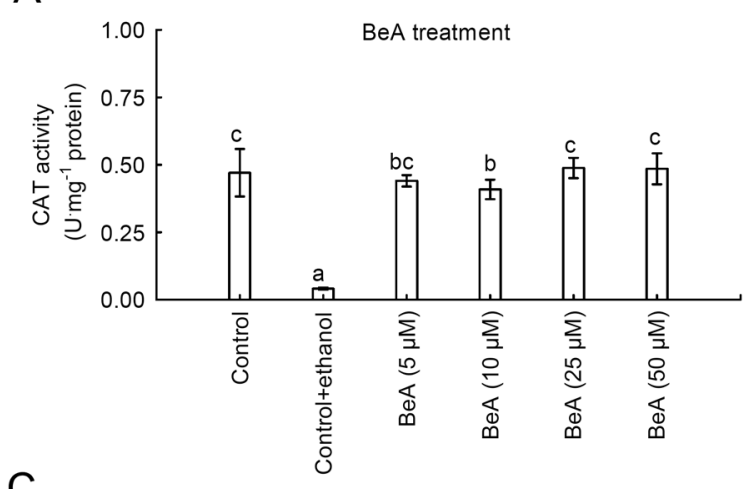

C

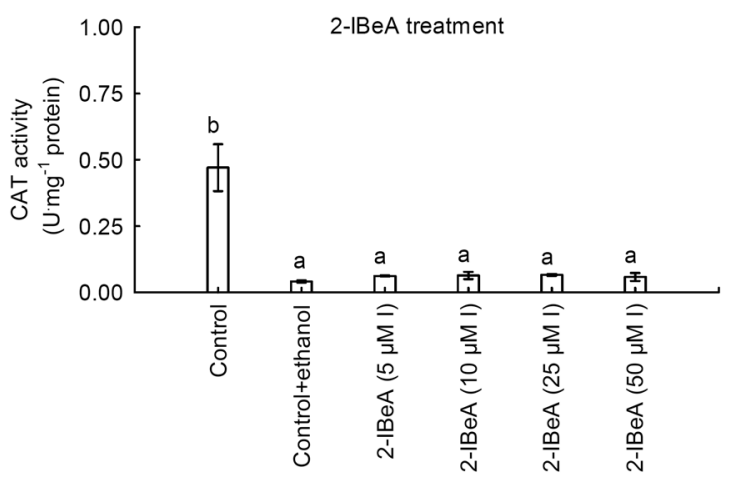

B

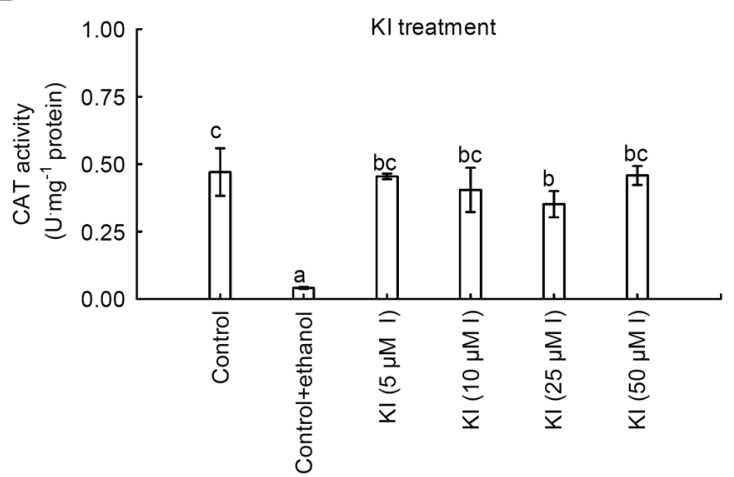

D

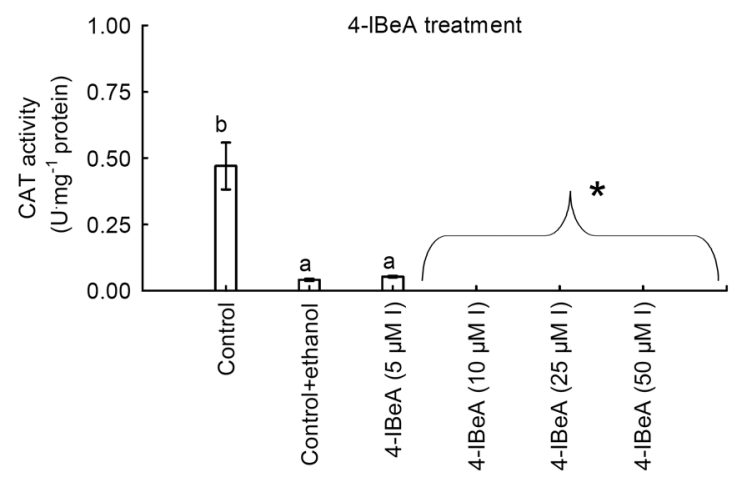

E

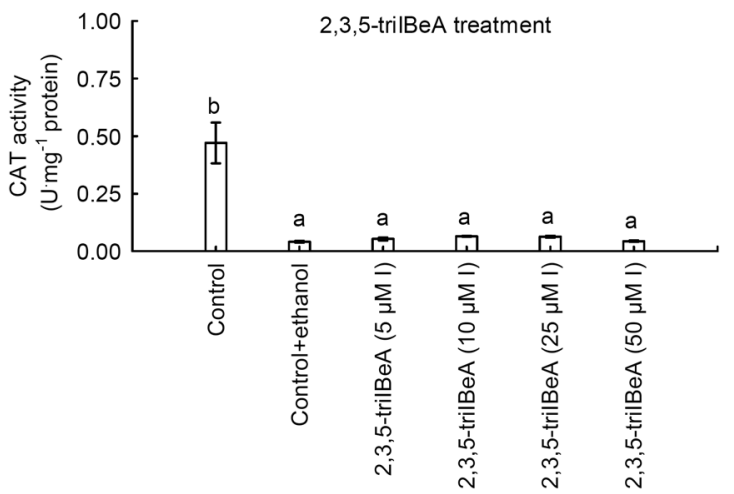

Figure 5. CAT activity in leaves of young tomato plants after $\mathrm{BeA}(\mathrm{A}), \mathrm{KI}(\mathrm{B}), 2-\mathrm{IBeA}(\mathrm{C}), 4-\mathrm{IBeA}(\mathrm{D})$ and 2,3,5-trilBeA (E) treatments. Means followed by the same letters are not significantly different for $p<0.05$. Bars indicate standard error $(n=8) . *$ The analysis was not done due to the lack of plant material due to the low yield in 4-IBeA treatment in $10 \mu \mathrm{M} \mathrm{I}, 25 \mu \mathrm{M}$ I and $50 \mu \mathrm{M} \mathrm{I}$ concentration (see Table 1).

\section{Sugar content in the leaves of tomato seedlings (see supplementary materials)}

Introduction of iodine compounds, as well as BeA into the nutrient solution, had a significant effect on glucose, fructose and sucrose content in the leaves of tomato seedlings (Table S1 in Supplementary Materials). In comparison to the control, there was a trend of increasing content of glucose, fructose and total sugars as well as the decreasing level of sucrose in tomato leaves after control + ethanol treatment.

The addition of $\mathrm{BeA}$ at the doses of $5-25 \mu \mathrm{M}$ to the nutrient solution led to a decrease in glucose level.
The content of fructose was reduced when BeA was applied in $10 \mu \mathrm{M}$ and $25 \mu \mathrm{M}$ doses, whereas sucrose level decreased only for the $50 \mu \mathrm{M}$ BeA. The increase of fructose content in leaves was observed only after $50 \mu \mathrm{M} \mathrm{BeA}$ application. The higher level of sucrose compared to control was noted only for $10 \mu \mathrm{M} \mathrm{BeA}$ application.

Application of all doses of an inorganic form of iodine (KI) led to a significant decrease of glucose, fructose, sucrose and total sugars content in leaves as compared to the control. The application of 2-IBeA at doses of $10 \mu \mathrm{M}$ I and $25 \mu \mathrm{M}$ I also reduced the content of all analysed 

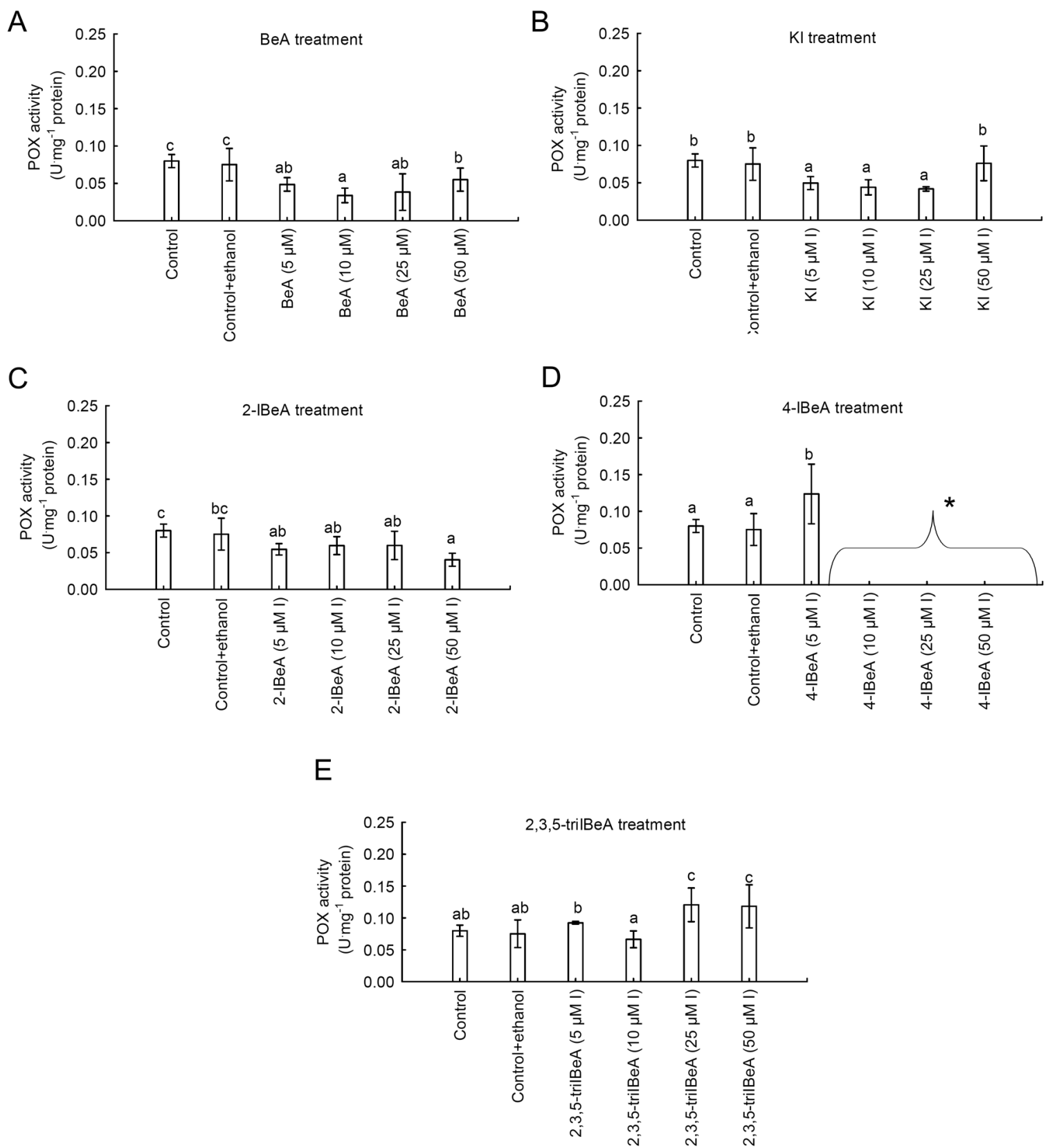

Figure 6. POX activity in leaves of young tomato plants after BeA(A), KI (B), 2-IBeA(C), 4-IBeA(D) and 2,3,5-trilBeA (E) treatments. Means followed by the same letters are not significantly different for $p<0.05$. Bars indicate standard error $(n=8) . *$ The analysis was not done due to the lack of plant material due to the low yield in 4-IBeA treatment in $10 \mu \mathrm{M} \mathrm{I}, 25 \mu \mathrm{M}$ I and $50 \mu \mathrm{M} \mathrm{I}$ concentration (see Table 1).

sugars in tomato leaves. However, the highest dose of 2-IBeA, i.e., $50 \mu \mathrm{M} \mathrm{I}$, did not affect the level of glucose, sucrose and total sugars accumulation in tomato plants. The 4-IBeA application did not influence glucose and fructose content but led to 1.3 times decrease of sucrose content in leaves. The iodine applied as 2,3,5-triIBeA at all doses did not modify glucose content in leaves. The application of that compound at doses of 5-25 $\mu \mathrm{M} \mathrm{I}$ caused $\approx 37 \%$ increase in fructose content. Nevertheless, the highest dose of 2,3,5-triIBeA $(50 \mu \mathrm{M}$ I) did not affect fructose content in leaves. When 2,3,5-triIBeA was applied in the doses of $10-50 \mu \mathrm{M} \mathrm{I}$, a decrease of sucrose content was observed. The lowest content of sucrose, as well as total sugars in tomato leaves, was noted after for $50 \mu \mathrm{M}$ I dose of 2,3,5-triIBeA.

\section{DISCUSSION}

\section{Iodine accumulation and the effect of iodine compounds on the growth and development of tomato seedlings}

Iodobenzoates, as well as iodosalicylates, can be taken up by tomato plants and then transported from the root system to the upper parts. These compounds can affect physiological and biochemical processes including plant 
yielding, SA and iodine methylation or its conversion (Halka et al., 2019b). All the applied iodine compounds contributed to a significant increase in iodine content in leaves, stems and roots of tomato seedlings. The noted increase was proportional to the applied doses of iodine. When iodine was applied in inorganic form as KI, it mostly got accumulated in the above-ground parts of the plant (stems $>$ leaves $>$ roots). For iodobenzoates, iodine was mostly found in the roots. The distribution of iodine in plants depended on the applied iodobenzoate. For 2-IBeA, iodine accumulation can be ranged as follows: roots $>$ stems $>$ leaves; for 4 -IBeA: stems $>$ roots $>$ leaves; whereas for 2,3,5-triIBeA: roots $>$ leaves $=$ stems.

The analysis of obtained results allowed to range the tested compounds with respect to its efficiency to increase iodine accumulation in leaves and stems in the following order: $\mathrm{KI}>4$-IBeA $>2$-IBeA $=2,3,5$-triIBeA $>$ control $=$ control + ethanol $=\mathrm{BeA}$, whereas for roots, the order was as follows: $2-\mathrm{IBeA}>4-\mathrm{IBeA}>\mathrm{KI}$ $>$ 2,3,5-triIBeA $>$ control $=$ control + ethanol $=$ BeA. A predominant accumulation of iodine applied as iodobenzoates in the roots may be related to its more complex structure compared to iodides. The presence of aromatic ring in the structure of iodobenzoates may limit the transport of these compounds into the upper parts of the plants. The hypothesis is that iodine from aromatic compounds is characterised by weaker translocation than the ionic forms $\left(\mathrm{I}^{-}\right.$and $\left.\mathrm{IO}_{3}^{-}\right)$that are supposed to be transported through the same channels as chlorides. Iodobenzoates are larger molecules than inorganic iodine ions. Thus, theoretically, its transport may encounter more difficulties taking into account the size and nature of the molecule.

Inorganic forms of iodine (iodides, iodates), when applied in low doses, positively affect the growth and development of higher plants as well as increase plant tolerance to various stress factors (Medrano-Macías et al., 2016a). However, high concentrations of iodine may become toxic and therefore cause plant damage. Application of inorganic forms of iodine in doses above $10 \mathrm{mM}$ caused toxicity symptoms in tomato plants such as leaf chlorosis, epinasty and visible wilting (Kiferle et al., 2013). In our previous studies, the application of iodosalicylates such as 5-ISA and 3,5-diISA in significantly lower concentrations, i.e., $5 \mu \mathrm{M} \mathrm{I}, 10 \mu \mathrm{M}$ I, $25 \mu \mathrm{M} \mathrm{I}$ and $50 \mu \mathrm{M} \mathrm{I}$, did not cause any negative effect on the growth of leaves and roots of young tomato plants (Halka et al., 2019a). The reduction of stem biomass was observed only for 3,5-diISA applied in doses of $10 \mu \mathrm{M} \mathrm{I}$ and $25 \mu \mathrm{M}$ I (Halka et al., 2019a). In the present work, among all tested compounds and its concentrations, a negative effect on plant growth was noted only for 4-IBeA applied in doses of $10 \mu \mathrm{M} \mathrm{I}, 25$ $\mu \mathrm{M} \mathrm{I}$ and $50 \mu \mathrm{M} \mathrm{I}$. An improvement of plant growth was noted for 2-IBeA and 2,3,5-triIBeA. However, the application of higher doses of 2,3,5-triIBeA (10 $\mu \mathrm{M} \mathrm{I}$, $25 \mu \mathrm{M} \mathrm{I}$ and $50 \mu \mathrm{M} \mathrm{I}$ ) led to the formation of elongated and twisted stems. 2,3,5-triIBeA, known as TIBA, is a compound classified as an inhibitor of polar auxin transport in plants (Rincon et al., 2003) that plays an important role in plant development processes such as cell elongation and division, differentiation of vascular tissues and root formation (Lomax et al., 1995). Studies conducted by Kucharska et al. (2012) on rose plants have revealed that the addition of 2,3,5-triIBeA into the regeneration medium in a concentration of $2.5 \mathrm{mg} \cdot \mathrm{L}^{-1}$ increases the number of leaves and adventitious shoots as well as intensifies shoot regeneration. The inhibition of the growth of tomato seedlings noted after the application of higher concentrations of 4-IBeA may be probably related to a stronger effect of that compound on phytohormone homoeostasis in tomato than that exerted by 2,3,5-trilBeA (Halka et al., 2019b).

\section{Metabolism of ascorbate in tomato seedlings}

AA plays an important role in plant organism affecting the processes of photosynthesis as well as the synthesis of anthocyanins, gibberellins and ethylene. AA is one of the major non-enzymatic antioxidants that also regulates plant growth and development (Wang et al., 2013). Together with APX, AA is involved in the Mehler peroxidase reaction that regulates redox state of photosynthetic electron carriers (Smirnoff and Wheeler, 2000). AA is easily oxidised to DHA through monodehydroascorbate (MDHA). The process is catalysed by ascorbate oxidase (AO) and APX (Venkatesh and Park, 2014). DHA is a less stable form than the reduced form (AA) (Smirnoff, 1996). A significant effect of tested compounds on the content of AA and DHA in tomato leaves was noted in our studies (Figures 3 and 4). The application of BeA contributed to a decrease of AA only when applied in a $5 \mu \mathrm{M}$ dose. A decrease of AA content was noted for all concentrations of KI. After the application of 2-IBeA in $5 \mu \mathrm{M} \mathrm{I}, 25 \mu \mathrm{M}$ I and $50 \mu \mathrm{M}$ I doses, no modifications of AA content were observed. Only in the case of 10 $\mu \mathrm{M}$ I dose of that compound, a decrease of AA level in tomato leaves was noted. It was, most likely, related to intensified AA oxidation into DHA or smaller degree of DHA reduction as reflected by an increased content of the latter compound in tomato leaves from that combination. Application of 4-IBeA to the plants resulted in the simultaneous decrease of AA and DHA in tomato leaves. Possibly, it was related to the oxidative stress that may have occurred in plants additionally decreasing plant biomass and growth limitation in the combinations with higher doses of 4-IBeA (Table 1). Introduction of higher doses of 2,3,5-trilBeA decreased the level of AA in tomato leaves, which, similarly to 4-IBeA, may have resulted from the toxicity effect.

APX catalyses the reduction of $\mathrm{H}_{2} \mathrm{O}_{2}$ to $\mathrm{H}_{2} \mathrm{O}$ with ascorbate as an electron donor, which is also converted into MDHA. The MDHA can regenerate ascorbate and be converted into DHA (Hasanuzzaman et al., 2019). Exogenous iodine, applied either as inorganic or organic compounds such as iodosalicylates, may 
affect the activity of APX and, consequently, the metabolism of AA (Halka et al., 2019a). There are a few studies describing the effect of mineral iodine form as $\left(\mathrm{I}^{-}\right)$and $\left(\mathrm{IO}_{3}^{-}\right)$on APX activity (Blasco et al., 2011a; Medrano-Macías et al., 2016b). The exact molecular, physiological and biochemical mechanisms of action of organic iodine compounds on the activity of APX is not known. This problem should be the subject of more detailed research. In our study, the application of $\mathrm{BeA}$ in all tested concentrations did not exhibit such an effect on APX activity in the leaves of tomato seedlings. Only low concentrations of KI $(5 \mu \mathrm{M}$ I and $10 \mu \mathrm{M} \mathrm{I})$ reduced APX activity in tomato leaves, while after the application of higher KI dose, i.e., $25 \mu \mathrm{M}$ I and $50 \mu \mathrm{M}$ I an increase in the activity of that enzyme was noted. A research conducted by Blasco et al. (2011a) revealed the lack of significant influence of $\mathrm{I}^{-}$on APX activity in lettuce leaves and the increase of that parameter after the application of $\mathrm{IO}_{3}^{-}$.

In the present study, APX activity tends to decrease after the application of all iodobenzoates as well as in the control + ethanol combination (Figure 4). The previous work on tomato seedlings has revealed a similar relation between APX activity and 3,5-diiodosalicylic acid (Halka et al., 2019a). In the case of 5-ISA, a decrease of APX activity was noted only for the $5 \mu \mathrm{M}$ I dose (Halka et al., 2019a). It can be therefore concluded that the reaction of tomato plants on high doses of iodine varies depending on the applied inorganic and organic form of that element. For the latter one, the number and location of iodine atoms bound into the aromatic ring of iodosalicylates and iodobenzoates are also important. It seems likely that the application of iodosalicylates and iodobenzoates may activate diverse protective pathways against ROS than the application of inorganic iodine forms such as iodides and iodates.

\section{Catalase and guaiacol peroxidase activity}

CAT and POX belong to plant antioxidant enzymes (Cavalcanti et al., 2004; Mhamdi et al., 2010). A typical process catalysed by CAT is $\mathrm{H}_{2} \mathrm{O}_{2}$ dismutation into $\mathrm{H}_{2} \mathrm{O}$ and $\mathrm{O}_{2}$ (Mhamdi et al., 2010); POX is involved in $\mathrm{H}_{2} \mathrm{O}_{2}$ detoxification through oxidation of phenolic and endiolic co-substrates (Cavalcanti et al., 2004). It has been revealed that iodine biofortification of plants affects the activity of CAT and POX in plant tissues (Blasco et al., 2011a; Gupta et al., 2015; Halka et al., 2019a). Application of $20 \mu \mathrm{M}, 40 \mu \mathrm{M}$ and $80 \mu \mathrm{M}$ doses of $\mathrm{I}^{-}$ and $\mathrm{IO}_{3}^{-}$during the cultivation increased CAT activity in the lettuce plants with the highest values noted for $80 \mu \mathrm{M} \mathrm{IO}_{3}^{-}$(Blasco et al., 2011a). Studies conducted by Gupta et al. (2015) on Glycine max L. plants cultivated under heavy metal stress also indicated an increase of CAT activity when $\mathrm{IO}_{3}^{-}$was additionally applied in 20 $\mu \mathrm{M}, 40 \mu \mathrm{M}$ and $80 \mu \mathrm{M}$ doses. In the current experiment on tomato seedlings, no effect of KI on CAT activity was noted (except $25 \mu \mathrm{M}$ I dose). A significant drop in CAT activity of tomato leaves was noted after the application of all doses of iodobenzoates: 2-IBeA, 4-IBeA and 2,3,5-triIBeA. Previous research on young tomato plants indicated that the application of 5-ISA and 3,5-diISA also slightly lowered the activity of CAT (Halka et al., 2019a), yet the level of reduction caused by iodosalicylates was less substantial than the effect of iodobenzoates noted in the present work. BeA is a direct precursor of SA that may exert an inhibiting action on CAT activity (Chen and Klessing, 1991; Chen et al., 1993). In the present study, no statistically significant effect of BeA on CAT activity was noted which may justify the assumption of reduced CAT activity as a specific response of tomato seedlings to exogenous iodobenzoates (2-IBeA, 4-IBeA and 2,3,5-triIBeA).

A significant decrease in CAT activity was observed in the control + ethanol combination. The tested iodobenzoates were dissolved in a few drops of ethanol due to its low solubility in water. Therefore, a synergistic effect of iodobenzoates and ethanol on the reduction of CAT activity in tomato seedlings may have been observed.

In the present work, it has been revealed that tested iodine compounds reduced the activity of POX enzyme in the leaves of tomato seedlings. Only in the case of $5 \mu \mathrm{M}$ I dose of 4-IBeA and higher doses of 2,3,5-triIBeA $(25 \mu \mathrm{M}$ I and $50 \mu \mathrm{M}$ I) a significant increase in POX activity was noted as compared to the control. Research conducted on tomato seedlings by Medrano-Macías et al. (2016b) revealed the lack of effect of inorganic forms of iodine $\mathrm{I}^{-}$and $\mathrm{IO}_{3}^{-}$on the activity of that enzyme. Our previous work on young tomato plants showed a modified level of POX activity that depended on the dose and chemical form of applied iodine (Halka et al., 2019a). The tested organoiodine compounds are derivatives of $\mathrm{BeA}$, which also has been shown to affect the POX activity. Studies conducted by Yadav and Singh (2013) revealed that additional application of exogenous BeA may improve POX activity in wheat seedlings grown in stress conditions caused e.g., by heavy metals (Yadav and Singh, 2013). Most probably, the increase in POX activity in combinations with higher doses of 4-IBeA and 2,3,5-triIBeA $(25 \mu \mathrm{M}$ I and $50 \mu \mathrm{M} \mathrm{I})$ has been related to increased stress level resulting from iodine and/or iodobenzoate accumulation in plant tissues.

\section{Sugars content in leaves of tomato seedlings (see: supplementary materials)}

Iodine biofortification may affect the level of glucose, fructose and sucrose accumulation in plant tissues (Blasco et al., 2011b; Kiferle et al., 2013; Smoleń et al., 2016). Also in the present study, the content of these compounds in tomato seedlings varied in tested combinations. Application of BeA in $5 \mu \mathrm{M}, 10 \mu \mathrm{M}$ and $25 \mu \mathrm{M}$ doses reduced the content of glucose and fructose while increasing the level of sucrose in tomato seedlings. Introduction of the highest dose of that compound (50 $\mu \mathrm{M} \mathrm{BeA})$ led to adverse observation 
i.e. increase of the fructose and reduction of sucrose content. The inorganic form of iodine as KI led to a decrease of the content of all analysed sugars. Application of 2-IBeA in 5-25 $\mu \mathrm{M}$ I doses slightly decreases the content of sugars. At the same time, the highest dose of that compound increased the level of fructose with no effect on sucrose accumulation. In the case of 4-IBeA, only its lowest dose modified the level of sugar accumulation, namely by reducing the level of sucrose. Plant growth in the presence of 2,3,5-triIBeA in the nutrient solution did not affect glucose accumulation, yet low doses of that compound (5-10 $\mu \mathrm{M}$ I) increased the accumulation of fructose. In studies with lettuce, a different plant response in terms of sugar content fructose, glucose and sucrose was found under the influence of $\mathrm{KIO}_{3}$ and 5-ISA application (Smoleń et al., 2017). Our previous studies on tomato in the seedling phase have shown that after the application of iodosalicylates (5-ISA, 3,5-diISA) and iodobenzoates (2-IBeA, 4-IBeA) there is an increase of glucose and fructose content in the leaves compared to control and KI as a source of iodine (Halka et al., 2019c). Meanwhile, the present research shows that the sugar content in the leaves of tomato seedlings depends not only on the type of iodobenzoate but also on its dose.

\section{CONCLUSIONS}

The effect of organic compounds of iodine on plants is poorly documented. Iodine in the form of iodobenzoates probably was taken up, accumulated and distributed in tomato seedlings differently than KI (this effect was observed in previous studies on tomato plants in the fruiting phase (Halka et al., 2019b)). When KI was applied, iodine was mainly found in the above-ground parts of the plant, whereas for 2-IBeA, 4-IBeA and 2,3,5-triIBeA, in the root system. Such an observation indicates a weaker transport of iodobenzoates or the products of its metabolism into the leaves.

A negative effect on plant growth and development was revealed for 4-IBeA applied in 10-50 $\mu \mathrm{M}$ I doses. On the other hand, the application of 2,3,5-trilBeA in doses within the range of 10-25 $\mu \mathrm{M}$ I impaired the growth but did not affect the final biomass of tomato seedlings. The tested iodobenzoates affected the metabolism of AA in tomato plants with the particularly decreasing effect exerted on APX activity. The applied inorganic and organic forms of iodine variously modified the activity of CAT and POX enzymes in tomato leaves. The mechanisms responsible for plant response to oxidative stress were variously affected by the iodine compounds present in the nutrient solution.

\section{ACKNOWLEDGEMENTS}

This work was supported by the Ministry of Science and Higher Education of the Republic of Poland. The application of the organic form of iodine into plants was taken from our patented solution Sady, W., Smoleń S., Ledwożyw-Smoleń, I. Methods of biofortification of vegetables with iodine. Patent No. P.410806, Polish Patent Office 20.11.2017.

\section{AUTHOR CONTRIBUTION}

H.M. and S.S. were responsible for planning the experiment, conducting plant cultivation, analysis of plant material, results interpretation and writing the manuscript. L.-S.I. conducted chemical analyses as well as manuscript preparation.

\section{CONFLICT OF INTEREST}

We inform that the manuscript has not been submitted for publication elsewhere. All co-authors have contributed to this article and all have agreed to submit it into this journal. There is no conflict of interests.

\section{REFERENCES}

BEERs, R. F., AND SizER, I. W. (1952). A spectrophotometric method for measuring the breakdown of hydrogen peroxide by catalase. Journal of Biological Chemistry, 195(1), 133-140.

Blasco, B., Rios, J. J., Cervilla, L. M., SánchezRodrigez, E., Ruiz, J. M., And Romero, L. (2008). Iodine biofortification and antioxidant capacity of lettuce: potential benefits for cultivation and human health. Annals of Applied Biology, 152, 289-299.

Blasco, B., Rios, J. J., Leyva, R., Cervilla, L. M., SÁnchez-Rodrigez, E., Rubio-Wilhelmi, M. M., Ruiz, J. M., And Romero, L. (2011a). Does iodine biofortification affect oxidative metabolism in lettuce plants? Biological Trace Element Research, 142, 831-842.

Blasco, B., Rios, J. J., Leyva, R., Melgarejo, R., Constán-Aguilar, C., Sánchez-Rodríguez, E., Rubio-Wilhelmi, M. M., Romero, L., And Ruiz, J. M. (2011b). Photosynthesis and metabolism of sugars from lettuce plants (Lactuca sativa L. var. longifolia) subjected to biofortification with iodine. Journal of Plant Growth Regulation, 65, 137-143.

Cavalcanti, F. R., ABreU Oliveira, J. T., MartinsMiranda, A. S., Viégas, R. A., and Silveira, J. A. G. (2004). Superoxide dismutase, catalase and peroxidase activities do not confer protection against oxidative damage in salt-stressed cowpea leaves. New Phytologist, 163, 563-571.

Chen, Z., And Klessig, D. F. (1991). Identification of a soluble salicylic acid-binding protein that may function in signal transduction in the plant diseaseresistance response. Proceedings of the National Academy of Sciences of the United States of America, 88, 8179-8183.

Chen, Z., Ricigliano, J. W., and Klessig, D. F. (1993). Purification and characterization of a soluble salicylic acid-binding protein from tobacco. Proceedings 
of the National Academy of Sciences of the United States of America, 90, 9533-9537.

Dresler, S., And Maksymiec, W. (2013). Capillary zone electrophoresis for determination of reduced and oxidised ascorbate and glutathione in roots and leaf segments of Zea mays plants exposed to $\mathrm{Cd}$ and $\mathrm{Cu}$. ACTA Scientiarum Polonorum, Hortorum Cultus, 12, 143-155.

Gonella, M., Renna, M., D'imperio, M., Santamaria, P., And SERIo, F. (2019). Iodine biofortification of four Brassica genotypes is effective already at low rates of potassium iodate. Nutrients, 11, 451.

Gonzali, S., Kiferle, C., And Perata, P. (2017). Iodine biofortification of crops: agronomic biofortification, metabolic engineering and iodine bioavailability. Current Opinion in Biotechnology, 44, 16-26.

Gupta, N., Bajpai, M., Majumdar, R., and Mishra, P. (2015). Response of iodine on antioxidant levels of Glycine max L. grown under $\mathrm{Cd}^{2+}$ stress. Advances in Biological Research, 9, 40-48.

Halka, M., Smoleń, S., Ledwożyw-Smoleń, I., And SADY, W. (2019a). Comparison of effects of potassium iodide and iodosalicylates on the antioxidant potential and iodine accumulation in young tomato plants. Journal of Plant Growth Regulation, 39, 282-295.

Halka, M., Smoleń, S., Czernicka, M., KlimekChodacka, M., Pitala, J., and Tutaj, K. (2019b). Iodine biofortification through expression of $H M T$, SAMT and $S 3 H$ genes in Solanum lycopersicum L. Plant Physiology and Biochemistry, 144, 35-48.

Halka, M., Smoleń, S., Ledwożyw-Smoleń, I., Sady, W. (2019c). Iodosalicylates and iodobenzoates supplied to tomato plants affect the antioxidative and sugar metabolism differently than potassium iodide. Folia Horticulturae, 31(2), 385-400.

Hasanuzzaman, M., Borhannuddin, B. M. H. M., Islam Anee, T., Parvin, K., Nahar, K., Jubayer AL Mahmud, J., And Fujita, M. (2019). Regulation of ascorbate-glutathione pathway in mitigating oxidative damage in plants under abiotic stress. Antioxidants, 8, 384.

Hoagland, D. R., And Arnon, D. I. (1950). The waterculture method for growing plants without soil (p. 347). Berkeley, USA: Agricultural Experiment Station.

Kaur, H., Inderuit., And Kaushik, S. (2005). Cellular evidence of allelopathic interference of benzoic acid to mustard (Brassica juncea L.) seedling growth. Plant Physiology and Biochemistry, 43, 77-81.

Kiferle, C., Gonzali, S., Tualling Holwerda, H., Real Ibaceta, R., and Perata, P. (2013). Tomato fruits: A good target for iodine biofortification. Frontiers in Plant Science, 4(205), 205.

Kucharska, D., Orlikowska, T., Stępowska, A., AND Dyki, B. (2012). The influence of TIBA on adventitious shoot induction of rose cultivars. Propagation of Ornamental Plants, 12(2), 109-116.

Lomax, T. L., Muday, G. K., And Rubery, P. H. (1995). Auxin transport. In P. J. Davies (Ed.), Plant hormones (pp. 509-530). Dordrecht, Netherlands: Kluwer Academic Publishers.

Medrano-Macías, J., Leija-Martínez, P., GonzálesMorales, S., Juárez-Maldonado, A., And Benavidez-MendozA, A. (2016a). Use of iodine to biofortify and promote growth and stress tolerance in crops. Frontiers in Plant Science, 7, 1146.

Medrano-Macías, J., LeiJa-Martínez, P., JuárezMaldonado, A., Rocha-Estrada, A., And BenavidezMendozA, A. (2016b). Effect of iodine application on antioxidants in tomato seedlings. Revista Chapingo, Serie Horticultura, 22, 122-143.

Mhamdi, A., Queval, G., Chaouch, S., Vanderauwera, S., Van Breusegem, F., And Noctor, G. (2010). Catalase function in plants: a focus on Arabidopsis mutants as stress-mimic models. Journal of Experimental Botany, 61(15), 4197-4220.

NAKANO, Y., AND AsAdA, K. (1981). Hydrogen peroxide is scavenged by ascorbate-specific peroxidase in spinach chloroplasts. Plant and Cell Physiology, 22, 867-880.

PN-EN15111. (2008). Food stuffs-determination of trace elements-determination of iodine by ICP-MS (Inductively Coupled Plasma Mass Spectrometry). Warsaw: Polish Committee of Standardization. (In Polish).

Reuveni, R., Shimoni, M., Karchi, Z., And Kuc, J. (1992). Peroxidase activity as a biochemical marker for resistance of muskmelon (Cucumis melo) to Pseudoperonospora cubensis. Phytopathology, 82, 749-753.

Rincon, A., Priha, O., Sotta, B., Bonnet, M., and LE TACON, F. (2003). Comparative effects of auxin transportinhibitors on rhizogenesis and mycorrhizal establishment of spruce seedlings inoculated with Laccaria bicolor. Tree Physiology, 23, 785-791.

Senaratna, T., Merritt, D., Dixon, K., Bunn, E., Touchell, D., and Sivasithamparam, K. (2003). Benzoic acid may act as the functional group in salicylic acid and derivatives in the induction of multiple stress tolerance in plants. Plant Growth Regulation, 39, 77-81.

Smirnoff, N. (1996). The function and metabolism of ascorbic acid in plants. Annals of Botany, 78, 661669.

Smirnoff, N., And Wheeler, G. L. (2000). Ascorbic acid in plants: biosynthesis and function. Critical Reviews in Biochemistry and Molecular Biology, 35, 291-314.

Smoleń, S., Kowalska, I., Czernicka, M., HalKa, M., KęSKa, K., and SAdy, W. (2016). Iodine and selenium biofortification with additional application of salicylic acid affects yield, selected molecular parameters and chemical composition of lettuce plants (Lactuca sativa L. var. capitata). Frontiers in Plant Science, 7, 1553.

Smoleń, S., Ledwożyw-Smoleń, I., Halka, M., SAdy, W., AND KovÁčIK, P. (2017). The absorption of iodine 
from 5-iodosalicylic acid by hydroponically grown lettuce. Scientia Horticulturae, 225, 716-725.

Van Hees, P. A. W., Lundström, U. S., And Giesler, R. (2000). Low molecular weight organic acids and their Al-complexes in soil solution-composition, distribution and seasonal variation in three podzolized soils. Geoderma, 94, 173-200.

Venkatesh, J., And Park, S. W. (2014). Role of L-ascorbate in alleviating abiotic stresses in crop plants. Botanical Studies, 55(1), 38.

Vlot, A. C., Dempsey, D. A., And Klessing, D. F. (2009). Salicylic acid, a multifaceted hormone to compat disease. Annual Review of Phytopathology, 47, 177-206.

Wang, X., Lou, X., Mo, Z., XInG, M., MaO, G., Zhu, W., Wang, Y., Chen, Y., And Wang, Z. (2019). Poor iodine knowledge, coastal region, and non-iodized salt consumption linked to low urinary iodine excretion in Zhejiang pregnant women. Nutrients, 11(2), 413.

Wang, J., Zhang, Z., And Huang, R. (2013). Regulation of ascorbic acid synthesis in plants. Plant Signaling and Behavior, 8(6), e24536, doi: 10.4161/psb.24536.

WAterborG, J. H. (2002). The Lowry method for protein quantitation. In J. M. Walker (Ed.), The protein protocols handbook (pp. 7-10). Totowa, NJ: Humana Press Inc.

Weng, H.-X., Yan, A.-L., Hong, C.-L., Xie, L.-L., Qin, Y.-C., AND ChenG, C. Q. (2008). Uptake of different species of iodine by water spinach and its effect to growth. Biological Trace Element Research, 124, 184-194.

Widhalm, J. R., and Dudareva, N. (2015). A familiar ring to it: Biosynthesis of plant benzoic acids. Molecular Plant, 8(1), 83-97.

Winger, R. J., König, J., And House, D. A. (2008). Technological issues associated with iodine fortification of foods. Trends in Food Science and Technology, 19, 94-101.

WORLD HEALTH ORGANIZATION. (2007). International Council for Control of Iodine Deficiency Disorders. United Nations International Children's Emergency Fund. Assessment of iodine deficiency disorders and monitoring their elimination. A guide for programme managers. Geneva, Switzerland: WHO.

YAdAv, K., AND Singh, N. B. (2013). Effects of benzoic acid and cadmium toxicity on wheat seedlings. Chilean Journal of Agricultural Research, 73(2), 168-174.

ZhaO, Y. Q., Zheng, J. P., YAng, M. W., Yang, G. D., Wu, Y. N., AND Fu, F. F. (2011). Speciation analysis of selenium in rice samples by using capillary electrophoresis-inductively coupled plasma mass spectrometry. Talanta, 84, 983-988.

Received August 22, 2019; accepted September 2, 2020 


\section{SUPPLEMENTARY MATERIALS}

Table S1. Sugars content in leaves of young tomato plants

\begin{tabular}{|c|c|c|c|c|}
\hline Treatment & $\begin{array}{c}\text { Glucose } \\
\left(\mathrm{mg} \cdot 100 \mathrm{~g}^{-1} \text { f.w. }\right) \pm \mathrm{SE}\end{array}$ & $\begin{array}{c}\text { Fructose } \\
\left(\mathrm{mg} \cdot 100 \mathrm{~g}^{-1} \text { f.w. }\right) \pm \mathrm{SE}\end{array}$ & $\begin{array}{c}\text { Sucrose } \\
\left(\mathrm{mg} \cdot 100 \mathrm{~g}^{-1} \text { f.w. }\right) \pm \mathrm{SE}\end{array}$ & $\begin{array}{c}\text { Total sugars } \\
\left(\mathrm{mg} \cdot 100 \mathrm{~g}^{-1} \text { f.w. }\right) \pm \mathrm{SE}\end{array}$ \\
\hline Control & $34.10 \pm 0.90 \mathrm{c}$ & $43.64 \pm 0.53 \mathrm{c}$ & $23.47 \pm 1.16 \mathrm{c}$ & $130.08 \pm 3.69 \mathrm{e}$ \\
\hline Control+ethanol & $56.29 \pm 1.96 \mathrm{~d}$ & $89.51 \pm 1.37 \mathrm{e}$ & $12.00 \pm 0.49 \mathrm{a}$ & $154.46 \pm 2.98 \mathrm{~d}$ \\
\hline $\mathrm{BeA}(5 \mu \mathrm{M})$ & $23.14 \pm 1.19 b$ & $42.37 \pm 1.26 \mathrm{c}$ & $21.70 \pm 0.69 \mathrm{bc}$ & $87.20 \pm 1.23 b$ \\
\hline $\mathrm{BeA}(10 \mu \mathrm{M})$ & $22.30 \pm 0.90 \mathrm{ab}$ & $36.50 \pm 0.32 b$ & $30.21 \pm 1.46 \mathrm{~d}$ & $89.01 \pm 2.05 \mathrm{~b}$ \\
\hline $\mathrm{BeA}(25 \mu \mathrm{M})$ & $17.13 \pm 0.02 \mathrm{a}$ & $27.45 \pm 0.94 \mathrm{a}$ & $24.02 \pm 1.83 \mathrm{c}$ & $68.60 \pm 5.16 \mathrm{a}$ \\
\hline $\operatorname{BeA}(50 \mu \mathrm{M})$ & $35.96 \pm 0.46 \mathrm{c}$ & $59.51 \pm 1.58 \mathrm{~d}$ & $16.42 \pm 0.07 \mathrm{ab}$ & $111.89 \pm 5.01 \mathrm{c}$ \\
\hline Control & $34.10 \pm 0.91 \mathrm{c}$ & $43.64 \pm 0.54 \mathrm{c}$ & $23.47 \pm 1.14 \mathrm{c}$ & $130.08 \pm 3.70 \mathrm{c}$ \\
\hline Control+ethanol & $56.30 \pm 1.96 \mathrm{~d}$ & $89.51 \pm 1.38 \mathrm{~d}$ & $12.00 \pm 0.50 \mathrm{a}$ & $154.46 \pm 2.99 \mathrm{~d}$ \\
\hline $\mathrm{KI}(5 \mu \mathrm{M} \mathrm{I})$ & $15.44 \pm 0.71 \mathrm{a}$ & $27.33 \pm 1.86 \mathrm{a}$ & $11.04 \pm 0.26 \mathrm{a}$ & $53.81 \pm 3.18 \mathrm{a}$ \\
\hline KI (10 $\mu \mathrm{M} \mathrm{I})$ & $18.65 \pm 0.81 \mathrm{a}$ & $26.66 \pm 0.58 \mathrm{a}$ & $12.16 \pm 1.05 \mathrm{a}$ & $57.47 \pm 1.90 \mathrm{a}$ \\
\hline $\mathrm{KI}(25 \mu \mathrm{M} \mathrm{I})$ & $24.42 \pm 1.39 \mathrm{~b}$ & $37.45 \pm 1.32 \mathrm{~b}$ & $19.00 \pm 0.61 b$ & $80.87 \pm 4.93 b$ \\
\hline $\mathrm{KI}(50 \mu \mathrm{M} \mathrm{I})$ & $17.02 \pm 0.83 \mathrm{a}$ & $28.57 \pm 0.94 \mathrm{a}$ & $11.27 \pm 0.09 \mathrm{a}$ & $56.86 \pm 1.24 \mathrm{a}$ \\
\hline Control & $34.10 \pm 0.91 \mathrm{bc}$ & $43.65 \pm 0.53 b$ & $23.47 \pm 1.15 \mathrm{~d}$ & $131.00 \pm 3.70 \mathrm{~d}$ \\
\hline Control+ethanol & $56.29 \pm 1.95 \mathrm{~d}$ & $89.51 \pm 1.38 \mathrm{~d}$ & $11.99 \pm 0.49 \mathrm{ab}$ & $154.47 \pm 2.98 \mathrm{e}$ \\
\hline 2-IBeA $(5 \mu \mathrm{M} \mathrm{I})$ & $29.58 \pm 0.73 b$ & $46.27 \pm 0.20 \mathrm{~b}$ & $14.95 \pm 0.49 \mathrm{bc}$ & $91.13 \pm 3.72 \mathrm{c}$ \\
\hline 2-IBeA $(10 \mu \mathrm{M} \mathrm{I})$ & $17.40 \pm 0.58 \mathrm{a}$ & $29.25 \pm 0.32 \mathrm{a}$ & $10.84 \pm 1.01 \mathrm{a}$ & $57.49 \pm 2.20 \mathrm{a}$ \\
\hline $2-\mathrm{IBeA}(25 \mu \mathrm{M} \mathrm{I})$ & $20.85 \pm 0.81 \mathrm{ab}$ & $33.64 \pm 1.01 \mathrm{a}$ & $17.76 \pm 0.74 \mathrm{c}$ & $72.26 \pm 2.01 \mathrm{~b}$ \\
\hline 2-IBeA $(50 \mu \mathrm{M} \mathrm{I})$ & $39.84 \pm 3.85 \mathrm{c}$ & $64.79 \pm 2.07 \mathrm{c}$ & $23.98 \pm 0.44 \mathrm{~d}$ & $128.60 \pm 3.42 \mathrm{~d}$ \\
\hline Control & $34.11 \pm 0.90 \mathrm{a}$ & $43.64 \pm 0.54 \mathrm{a}$ & $23.47 \pm 1.16 \mathrm{~b}$ & $130.07 \pm 3.68 \mathrm{~b}$ \\
\hline Control+ethanol & $56.29 \pm 1.97 \mathrm{~b}$ & $89.51 \pm 1.36 b$ & $12.00 \pm 0.50 \mathrm{a}$ & $154.46 \pm 2.98 \mathrm{c}$ \\
\hline 4-IBeA $(5 \mu \mathrm{M} \mathrm{I})$ & $38.90 \pm 1.13 \mathrm{a}$ & $47.72 \pm 1.22 \mathrm{a}$ & $15.06 \pm 0.66 \mathrm{a}$ & $101.67 \pm 2.05 \mathrm{a}$ \\
\hline 4-IBeA $(10 \mu \mathrm{M} \mathrm{I})$ & $\mathrm{n} / \mathrm{a}$ & $\mathrm{n} / \mathrm{a}$ & $\mathrm{n} / \mathrm{a}$ & $\mathrm{n} / \mathrm{a}$ \\
\hline $4-\mathrm{IBeA}(25 \mu \mathrm{M} \mathrm{I})$ & $\mathrm{n} / \mathrm{a}$ & $\mathrm{n} / \mathrm{a}$ & $\mathrm{n} / \mathrm{a}$ & $\mathrm{n} / \mathrm{a}$ \\
\hline 4-IBeA $(50 \mu \mathrm{M} \mathrm{I})$ & $\mathrm{n} / \mathrm{a}$ & $\mathrm{n} / \mathrm{a}$ & $\mathrm{n} / \mathrm{a}$ & $\mathrm{n} / \mathrm{a}$ \\
\hline Control & $34.10 \pm 0.89 \mathrm{a}$ & $43.64 \pm 0.52 \mathrm{a}$ & $23.46 \pm 1.15 \mathrm{~d}$ & $130.08 \pm 3.69 \mathrm{~b}$ \\
\hline Control+ethanol & $56.29 \pm 1.95 b$ & $89.51 \pm 1.37 \mathrm{c}$ & $12.00 \pm 0.49 \mathrm{~b}$ & $155.06 \pm 2.98 \mathrm{c}$ \\
\hline 2,3,5-triIBeA $(5 \mu \mathrm{M} \mathrm{I})$ & $38.82 \pm 0.80 \mathrm{a}$ & $58.94 \pm 1.93 \mathrm{~b}$ & $23.49 \pm 0.53 \mathrm{~d}$ & $124.59 \pm 7.38 b$ \\
\hline 2,3,5-triIBeA $(10 \mu \mathrm{M} \mathrm{I})$ & $40.76 \pm 2.32 \mathrm{a}$ & $60.08 \pm 1.70 b$ & $16.82 \pm 1.07 \mathrm{c}$ & $117.66 \pm 4.45 \mathrm{~b}$ \\
\hline 2,3,5-triIBeA $(25 \mu \mathrm{M} \mathrm{I})$ & $37.15 \pm 0.30 \mathrm{a}$ & $61.71 \pm 1.49 \mathrm{~b}$ & $11.71 \pm 0.94 b$ & $110.57 \pm 6.11 \mathrm{~b}$ \\
\hline 2,3,5-triIBeA $(50 \mu \mathrm{M} \mathrm{I})$ & $34.32 \pm 1.20 \mathrm{a}$ & $46.70 \pm 2.87 \mathrm{a}$ & $4.81 \pm 0.33 \mathrm{a}$ & $85.82 \pm 0.96 \mathrm{a}$ \\
\hline
\end{tabular}

Means followed by the same letters are not significantly different for $p<0.05$

Statistical analysis was conducted for each part of tomato plants separately, $(n=8)$.

$\mathrm{n} / \mathrm{a}$ - the analysis was not done due to the lack of plant material due to the low yield in 4-IBeA treatment in 10,25 and $50 \mu \mathrm{M} \mathrm{I} \mathrm{concentration}$ (see Table 1) 